\title{
Monitoring Brain and Spinal Cord Metabolism and Function*
}

\author{
Pierre Pandin\#, Marie Renard, Alessia Bianchini, Philippe Desjardin, Luc Van Obbergh \\ Department of Anesthesia \& Critical Care, Erasmus Academic Hospital, Université Libre de Bruxelles, Brussels, \\ Belgium \\ Email: \#ppandin@ulb.ac.be, "Pierre.Pandin@erasme.ulb.ac.be
}

Received 13 April 2014; revised 29 May 2014; accepted 19 June 2014

Copyright $@ 2014$ by authors and Scientific Research Publishing Inc.

This work is licensed under the Creative Commons Attribution International License (CC BY).

http://creativecommons.org/licenses/by/4.0/

(c) (i)

\begin{abstract}
Monitoring the metabolism and function of the central nervous system not only is an old idea but also is a topic that is of increasing interest to the technological evolution. Beside the optimization of cerebral and spinal cord perfusion and the preservation of vasoreactivity to ensure the viability of cerebral tissues and structures, we want to know more and more about the real intimate situation of these organs in real time at the patient's bedside. To this end, several tracks have been explored during the two last decades, leading to the development of numerous concepts and the conception of various monitoring systems. One of the main problems is to characterize the respective strong points and weaknesses of those ones and to conclude regarding their individual relevance and value in current clinical practice. It is more and more clear that the combination of different categories of monitoring is a way to try to find the most valuable technological compromise, to increase the chance of prediction or of early detection of intercurrent deleterious events corresponding to the concept of multimodality. The intraoperative period and the intensive care goals and targets are appreciably different. This is the reason for the attempt to define different and distinct sets of goals and targets for the intraoperative anesthetic setting and for the intensive care unit.
\end{abstract}

\section{Keywords}

Brain, Central Nervous System Monitoring, Metabolism, Function

\section{Introduction}

The most accurate possible monitoring of the metabolism and function of the central nervous system (CNS) re-

"Meeting at which this review has been presented: Annual meeting of the European Society of Anesthesia, EUROANAESTHESIA 2013, Barcelona, Spain, June 1st-4th 2013, Refresher Course 7RC2.

${ }^{*}$ Corresponding author.

How to cite this paper: Pandin, P., Renard, M., Bianchini, A., Desjardin, P. and Van Obbergh, L. (2014) Monitoring Brain and Spinal Cord Metabolism and Function. Open Journal of Anesthesiology, 4, 131-152. 
mains a cornerstone that is a testament to the constant technological evolution. It makes possible the more and more adapted management of the brain and the spinal cord during either more and more complex and specificneurosurgical interventions or more and more invasive investigations in neuro-intensive care unit (Neuro-ICU). For a long time now, the concept of active neuroprotection has been developed following the successive progress in the understanding of the complex interaction between the CNS, surgery, anesthesia, and/or a possible aggression (trauma, hemorrhage, ischemia, anoxia, edema, etc.). In the past, the pioneers used several rudimentary tools (for instance, the single trace analogue electroencephalogram), but unfortunately they were not integrated into the monitoring, and were without systematization or generalization (only used on a case-by-case basis). At the beginning of the nineties, a real neuro-monitoring culture emerged, as illustrated by the book edited by Peter Sebel and William Fitch, Monitoring the central nervous system [1]. Then, continuous efforts led to the conception of multimodal intraoperative monitoring (IOM), supported by pioneers as the American anesthesiologist Betty Grundy [2]-[4] and the English neurophysiologist Catherine Thornton [5] [6].

\section{CNS: What Is Metabolism and What Is Function?}

The specific functionality of well-defined neural loops or neural networks is now appreciated and their functioning seems to be governed by a biphasic on-off model [7] too often underestimated. Anesthesiologists and intensive care unit (ICU) specialists must change their mind about a more multimodal CNS monitoring for a more realistic vision of the function. Moreover, in the ICU, all the high-tech imaging innovations can give only a time to time idea of the neurological trend of the patients with sometime a lack a possible conclusion. On the other hand, in the operating room, the use of medical imaging remains limited for only very specific situations [8]. Alternatively, CNS follow-up regarding metabolism or function at the patient's bedside would be based on the combination of specific parameters not only regarding the experience of pioneers [9] [10] but also existing recommendations [11] [12] to depict with accuracy the topographical and temporal variability of the CNS [7].

\section{Early Detection for Outcome Improvement But Not Any Old How...}

Beside the early claimed dimension of global or segmental CNS investigation [13] [14], the early detection of the occurrence of possible troubles or abnormal events was advocated as well [2] [15], before permanent cerebral damage. The not only theoretical but desirable description of the fundamentals of this kind of monitoring is listed in Table 1. Their lack of materiality, fragility (micro or nanosignals respectively in $\mu \mathrm{V}$ and $\mathrm{nV}$ ), and sensitivity to electromagnetic disturbances make recording difficult, while the frequent intricacy between what is metabolism and what is function is not so simple to interpret [16] [17]. From a practical point of view, the neuromonitoring of metabolism and function is more and more subdivided into two distinct entities: intraoperative neuro-monitoring and neuro-monitoring in the ICU (Table 2) considering the goals of the monitoring, and the possible accessibility of the CNS.

\section{Temporal, Topographical, and Spatial Variations: The Brain Mapping Concept}

The complexity of the CNS lies probably not only in its structural complexity but also in its spatial and temporal metabolic and functional variability in either awake or comatose/unconscious patients, under anesthesia or in ICU [18]-[25]. To take that into account, neuro-monitoring has not to be too excessively simplified [26]-[28] and limited only to the forehead, as accurately described by John in his "anaesthetic cascade" [19]. Moreover, resorting to standard tools and technologies makes it easier to discuss the case with the neuro-specialists regarding the patient's management and the different options.

\section{Spontaneous Activities and Evoked Answers}

Regarding CNS function, one other specificity lies in the difference between spontaneous activities (as a description of the neurological ambiance) and evoked responses (as the reaction capability of the CNS to stimulation) as listed in the Table 3. Briefly, the clinician has to use the optimal multimodal combination of monitoring following, first, the pathophysiological target and second, the local culture and know-how, and third, the availability of the potential tools [9] [14]. The ambient signals (Table 2) inform directly or not about the metabolic level, more or less directly linked to the regional functional level, but are nevertheless limited by the risk to be too cumulative and not discriminant enough [29]-[32]. To bypass this problem, one solution is to map the skull 
Table 1. Theoretical description of the fundamentals of the ideal multimodal brain and spinal cord metabolism and function monitoring.

Theoretical description of the fundamentals of the ideal multimodal brain and spinal cord metabolism and function monitoring

Point 1: Global or segmental investigation of the central nervous system (CNS) with the possibility of individual adaptation following each case request

Point 2: Similar physiological dimension of the neurological indicators in comparison to the physiological hemodynamic or respiratory parameters-no calculation, no index

Point 3: Early detection of possible deterioration of neural function before definitive damage, because the sooner neural dysfunction is detected, the more reversible it is (usefulness of trends)

Point 4: Multimodality

Point 5: Subclinical detection of physiological or pathophysiological changes before the occurrence of major and definitive consequences to guide the earliest possible intervention to reduce and/or inverse the neural suffering, to improve the vital and functional prognosis of the patients by limiting the impact on the brain, spinal cord, or both

Point 6: Monitoring the versatility of either cerebral pathophysiology (stroke, ischaemia, haemorrhage, seizures, etc.) or pharmacological interaction (anaesthesia, barbiturates, anti-epileptic drugs, etc.)

Point 7: Make as much as possible the distinction between the anesthesiology and the effects of surgery on the pathophysiological process

Point 8: Make concrete not only CNS metabolism but also CNS function to make easier the management of anesthetised patients during the intraoperative period or comatose patients during their intensive care unit stay

Point 9: Apply the precepts of telemedicine and telemonitoring

Table 2. State of the art regarding the practice of neuro-monitoring during the intraoperative period vs. in the intensive care unit, based on differences in the practical conditions of realisation, goals and requests, and central nervous system accessibility (based on the literature, reflecting the actual worldwide practice "+++" corresponds to often used and/or even recommended monitoring, “++” is sometimes used and "+” matches for an occasional use. Alternatively, "-” corresponds to the lack of substantial clinical experience corresponding often to the impossibility of use, for several technical or practical reasons).

\section{Electrophysiology}

-Electroencephalogram

-Evoked potentials

Cerebral biochemistry

-Microdialysis

Cerebral brain oxygen

-SjvO2

-PbtO2

-SctO2 by NIRS

Cerebral blood perfusion (CBF)

-Regional CBF (TDF)

-Local CBF (LDF)

-TCD

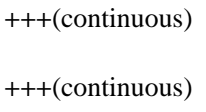

+++ discontinuous)

++(discontinuous)

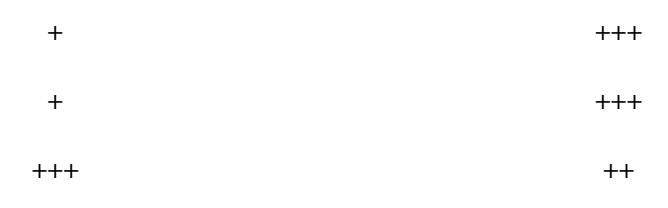

(1)


Table 3. Classification of central nervous system signals into spontaneous activities vs. evoked responses.

\begin{tabular}{|c|c|c|}
\hline Signals & Spontaneous & Evoked \\
\hline Basic principles & $\begin{array}{l}\text {-Direct \& immediate reading } \\
\text {-Topographical correlation } \\
\text {-Neural ambiance } \\
\text {-More basic }\end{array}$ & $\begin{array}{l}\text {-Indirect \& immediate reading (specific treatment) } \\
\text {-Anatomo-functional correlation } \\
\text {-Neural state } \\
\text {-More advanced }\end{array}$ \\
\hline General vs. global & $\begin{array}{l}\text {-Mapped EEG } \\
\text { (cEEG, dEEG, CEEG, sEEG, qEEG, QEEG) } \\
\text {-SvjO2 } \\
\text {-SctO2 (NIRS) }\end{array}$ & $\begin{array}{l}\text {-Mapped EP (brain or spinal cord) } \\
\text {-Mapped Sct02 (NIRS) EROS }\end{array}$ \\
\hline Regional vs. segmental & $\begin{array}{l}\text {-Microdialysis } \\
- \text {-PbtO2 } \\
- \text {-ICBF } \\
-r C B F \\
-T C D \& \text { microDoppler }\end{array}$ & -EP (SSEP, AEP, VEP, etc.) \\
\hline
\end{tabular}

Abbreviations: EEG: electroencephalogram; $c E E G$ : computerised EEG; $d E E G$ : digitised EEG; CEEG: continuous EEG; sEEG: simplified EEG; qEEG and QEEG: quantitative EEG; EP: evoked potentials; SSEP: somatosensory EP; AEP: auditory EP, VEP: visual EP; SvJO2: jugular venous oxygen saturation; SctO2:cerebral tissue oximetry; NIRS: near-infrared spectrometry; EROS: event-related evoked optical stimulation; PbtO2:brain tissue oxygen tension; ICBF: local cerebral blood flow; $r C B F$ : regional cerebral blood flow; $T C D$ : Transcranial Doppler.

surface with recording electrodes following a high enough resolution [24] [25], giving numerical or graphical trends [9] [14], useful for the early detection of potential neural degradation and to adapt the patient's management. Additionally, evoked responses can indicate the functional integrity or not of the neural networks [7] (audition, vision, somesthesia, motor function, nociception, etc.). Those ones, composed of neural loops through the different anatomical CNS levels, may help to locate the occurring problem and to assess the patient's prognosis [11]. In very disturbed and extreme conditions (brain death, deep hypothermia, etc.), the whole evoked responses are nearly completely depressed with a tremendous global decrease of CNS function, reversible or not.

\section{Multimodal Neuro-Monitoring in Addition to the Usual Measurements}

The combination of different neuro-parameters seems now to be logical regarding the capability to monitor the metabolism and/or the function of the brain and spinal cord, but the list of indicators to be combined is not yet fixed and depends on the specific clinical problem and situation of the patient. Moreover, the real impact on the final and the long-term outcome of neurological patients remains unclear, even if the preliminary but incomplete results seem to be interesting and convincing regarding a potential recommendation of the systematic use of neuro-monitoring [30] [31]. Monitoring of the central temperature, arterial and cerebral perfusion pressure, end tidal CO2, sequential arterial blood gas sampling, glycaemia follow-up, and, of course, monitoring of intracranial pressure (ICP) are currently recommended and always form part of CNS management, to maintain homeostasis, which indirectly preserves either the metabolism or function [33]. Therefore, multimodal neuro-monitoring must be a complement and not a replacement of what exists to achieve innovative solutions [33]. Until relatively recently, ICP remains a cornerstone in our practice when the brain is damaged [33]-[36]. Following the MonroKellie principle, the increase of intracranial volumes may result in brain herniation, reduction of cerebral blood flow (CBF), and of course, the rise of ICP is related to increased disability and mortality [37]. According to Treggiari's review [38], the raised but reducible ICP is associated with a three- to four-fold increase in the probability of death and/or poor neurological outcome, while a refractory ICP pattern is associated with a tremendous increase in the relative risk of death (odds ratio $>100$ ). One key point would be the aggressivity of the indications of ICP catheter insertion base on clinical (coma) and Computerized Tomography (CT) abnormality [38]. However, strong evidence seems to lack when ICP is considered to guide therapy in patients with acute brain injury [39] as illustrated by the recent Chesnut's [40] randomized controlled trial which demonstrated the lack of difference in 3- or 6-month outcomes in severe traumatic brain injury patients whose treatment was based on the ICP monitoring (strictly maintained below $20 \mathrm{mmHg}$ ) compared with those whose the follow-up was based on imaging (CTscan) and clinical examination without ICP monitoring. In this relatively controversial context, the spontaneous technological evolution gives to the clinicians a new opportunity to progressively monitoring the ICP by non-invasive methods as a sort of alternatives [41] [42]. The Transcranial Doppler (TCD) 
derived pulsatility index [41] [43], the intra-orbital optic nerve sonography [41] [44] [45] and the distorsionproduct otoacoustic emissions (DPOAEs) monitoring [46] have valuable preliminary results although insufficient for now. Despite the actual controversy, the ICP monitoring remains a key element of therapeutic strategies when it rises, even if it is not excluded to have to reevaluate its real interest during the next years leading to the publication of updated recommendations of use. Less and less on its own side; the ICP monitoring is integrated more and more into multimodal neuro-monitoring [16].

\section{Electrophysiology}

\subsection{Electroencephalogram (EEG) and Quantitative EEG (QEEG)}

More functional than metabolic, EEG measures the electrical activity related to the function of the outermost brain layer: the cerebral cortex is composed of different lobes dedicated to distinct superior functions, with metabolic and functional variations [47] [48]. The mapped QEEG is able to detect the occurrence of abnormal increases or decreases (sudden or progressive) in brain electrical activity [9] [10], clinically significant or not, in comatose, sedated, anesthetised, or awake patients. QEEG has a dual value [9] [49], to detect an increase or depression of brain electrical activity. In 50\% of cases, the seizures are nonconvulsive, completely silent or have an atypical clinical presentation [50] [51] potentially resulting in an increased secondary cerebral damage [52] and tissue loss [53] if they are not detected. The prevalence of nonconvulsive seizures varies between $4 \%$ to $30 \%$ [54] and is inextricably linked to sedation and anesthesia [55]. QEEG could have a real impact on not only the management of the prophylactic antiepileptic strategy, but also the final neurological outcome [56]. Within the QEEG-derived parameters, the variability in the alpha (awake) or the delta (coma or sleep) power may be helpful and relevant for the prediction of delayed ischemia in poor-grade subarachnoid haemorrhage [57] [58], to following the evolution in severe stroke patients [59], or to improve outcome in postanoxic comatose patients or after hypothermia [60]-[63]. Nevertheless, the implementation of QEEG in practice in anesthesia or critical care is challenging, requiring an interactive collaboration between anesthesiologists, ICU specialists and neurologists making supported by education and training of the participants on the ground (medical doctors, nurses), which is made easier in recent years by the development of telemedicine [64]-[68].

\subsection{Evoked Potentials}

The particularity of evoked potentials rests in their capability to monitor spinal cord function and indirectly monitor its metabolism [13]. By the judicious use of electrode montage, evoked potentials may inform about nervous conduction through the whole CNS until the different cerebral cortical lobes [69]-[71]. Similarly, their analysis may be global or segmental, and they can be divided into conduction index (subcortical) and in function index (cortical), as detailed in Table 4 and Table 5 [72]. Used worldwide, their usual indications are listed in Table 6 [73]-[77]. Evoked potentials are usually affected by inhalational agents [73]-[75] in their amplitudes rather than their latencies, and changes in body temperature (hypothermia), nervous tissue perfusion, oxygenation and ventilation (either oxygen or carbon dioxide), and ICP (rise) may depress them [30] [78] [79]. Nevertheless and despite these influences, the evoked potentials monitoring is very valuable, remains advanced, but is more and more associated with EEG or QEEG in clinical practice and is accepted as the gold standard [75]. On the other hand, motor evoked responses or potentials (MEPs) give information about centrifugal nervous "conduction” [76] after typically, a transcranial stimulation (TcMEP). MEPsare globally less sensitive to intercurrent factors and particularly to the impact of anesthetic drugs making them a strong functional monitoring used during spine and spinal cord surgery. MEP monitoring provides excellent specificity and sensitivity whenever the motor tracts are involved in the pathological process, particularly in trauma medicine. The actual recommendation is to combine TcMEP monitoring electrophysiological modalities [75].

\section{Microdialysis}

Only cerebral microdialysis (MCD)provides brain metabolism monitoring, because it reflects the biochemistry (glucose, lactate, pyruvate, lactate/pyruvate ratio, glutamate, urea, and anecdotal aspartate) of the cerebral tissue where the specialised catheter tip is implanted, giving an idea of the composition of the extracellular fluid [80], the adequacy of the brain energy supply, and cellular function. During cerebral ischaemia, an elevated lactate/ pyruvate ratio with an elevated glutamate and a low glucose indicate cellular hypoxia [81]. These metabolic 
Table 4. Evoked potential-derived subcortical index of conduction [58].

\begin{tabular}{cccc}
\hline Level of brain-stem lesion & SEPs & MLAEPs & BAEPs \\
1. MIDBRAIN & Normal P14 N20 delayed or absent & Abnormal & Normal \\
2. PONS & Normal P14 N20 delayed or absent & Abnormal \\
3. MEDULLA & Absent P14 N20 delayed or absent & Normal & Normal \\
\hline
\end{tabular}

SEPs: somatosensory evoked potentials; MLAEPs: midlatency auditory evoked potentials; BAEPs: brainstem auditory evoked potentials.

Table 5. Evoked potential-derived cortical index of function [58].

\begin{tabular}{ccc}
\hline Index of Global Cortical Function (IGCF) & VEPs & SEPs \\
Grade 0 & Normal & Normal \\
Grade 1 & Delayed peak III Peak VII present & Normal N20, P24, P27 N30 present \\
Grade 2 & Delayed peak III Peak VII present & Normal N20, P24 N30 basent \\
Grade 3 & Delayed peak III & Normal N20 \\
Grade 4 & No reproducible VEPs ERG present & P14 present \\
\hline
\end{tabular}

VEPs: visual evoked potentials; SEPs: somatosensory evoked potentials; ERG: electroretinogram.

Table 6. Classical applications of sensory evoked potentials.

Classical applications of sensory evoked potentials (EPs) during the intraoperative period and/or intensive care unit stay
Somatosensory EPs

1) Invasive spine (arthrodesis) and spinal cord surgery for detection of either medullary or radicular syndrome (combined with motor EPs and/or evoked EMG)

2) Normothermic thoracic and thoracoabdominal aortic surgery for detection of cord ischaemia (compromised vascular supplyradicular anterior Adamkiewicz artery_combined with motor EPs)

3) Deep or intermediate hypothermia for neurosurgery (cerebral vascular bypass), cardiac, or major vascular surgery (combined with motor EPs)

4) Carotid endarterectomy (alternative to mapped EEG and QEEG, because less pharmacologically depressible)

5) Surgical peripheral nerve release (surgery guidance-possibly combined with motor EPs)

6) Post-anoxic comatose patients (prognosis dimension—outcome prediction)

7) Hypothermic comatose patients (prognosis dimension-outcome prediction)

8) Spinal cord post-trauma status (combined with motor EPs and/or evoked EMG)

Auditory EPs (short or midbrain latencies)

1) Intra and extracranial surgery of the auditory and/or the facial nerves (combined with facial evoked EMG—specific facial nerve monitoring)

2) Midbrain and/or spinal cord post-trauma status (combined with motor EPs and/or evoked EMG)

Auditory EPs (middle or early cortical latencies)

1) Post-anoxic comatose patients (prognosis dimension-outcome prediction)

2) Hypothermic comatose patients (prognosis dimension-outcome prediction)

Auditory EPs (long or late cortical latencies)

1) Postoperative, post-lesion, or post-trauma cognitive dysfunction

Visual EPs (cortical latencies)

1) Optic nerve, hypothalamic, pituitary gland, and diaphragma sellae surgery

2) Post-anoxic comatose patients (prognosis dimension-outcome prediction)

3) Hypothermic comatose patients (prognosis dimension-outcome prediction)

EMG: electromyogram; EEG: electroencephalogram; $\mathbf{E E E G}$ : quantitative electroencephalogram. 
changes may occur before the usual cerebral physiological or pathophysiological changes [82] allowing earlier therapeutic adjustments. Some illustrative examples of successful MCD-motivated insulin therapy modifications have been published with the opportunity to determine individual optimal glycaemia threshold [80]-[85]. More and more often combined with the brain tissue oxygen tension (PbtO2), cerebral MCD is also able to optimise the Mean Arterial Pressure (MAP)/Cerebral Perfusion Pressure (CPP) [86] [87] and the transfusion thresholds [88] in patients at high risk of secondary brain ischaemia [89]. This has led to the establishment of guidelines in comatose patients for various problems [90] [91]. Moreover, a correlation has been demonstrated between variations in early biological markers and long-term outcome [92] supporting the concept of a possible influence of brain energy modulation on patient outcome. Despite these exciting results, MCD technology has an intrinsic limitation: the analysis is limited to the area surrounding the catheter tip, making this monitoring only local or even regional (Table 2). To bypass this problem, some successful experiences of multicatheter insertion have been reported, confirming the quality of the information provided by MCD, unfortunately too limited for now [93].

\section{Brain Oxygen Monitoring}

\subsection{Jugular Venous Oxygen Saturation (Sjv02)}

In this category of CNS monitoring, $\mathrm{SjvO} 2$ is the oldest since it was proposed in clinical practice from the 1940s. After a resurgence at the beginning of the 1990s, sustained by the availability of fibreoptic oximetric catheters, there has been a progressive lack of interest, which is related to the intrinsic weaknesses of this parameter and the concomitant emergence of new competitive technologies (see below). The difficulty of keeping the tip of the catheter in a good place (despite some attempts of ultrasound-guided optimisation, which was unfortunately not generalised), with the correlated high risk of displacement, particularly in awake but non-cooperative patients [94] [95]; the possibility of extracranial blood contamination; the lack of sensibility and specificity to detect limited brain ischaemia have often made the rational interpretation of SjvO2 too difficult and non-pertinen [96]. This is why, nowadays, $\mathrm{SjvO} 2$ is progressively competed by newer technologies.

\subsection{Brain Tissue Oxygen Tension}

The brain oxygen supply depends on cerebral blood flow (CBF), and the partial pressure of oxygen in brain tissue or brain oxygen $(\mathrm{PbtO} 2$ = product of $\mathrm{CBF}$ and cerebral arteriovenous oxygen tension difference) represents an effective indicator that is, nevertheless, more indicative of oxygen diffusion than cerebral metabolism [97]. $\mathrm{PbtO} 2$ is measured on-line via specific probes inserted in subcortical white matter, through multiple-lumen bolts adjacent to ICP monitors, but can also be measured in penumbral tissue, such as around haemorrhagic contusions or in areas at risk for secondary delayed vasospasm/ischaemia. Furthermore, $\mathrm{PbtO} 2$ is additional to ICP monitoring in guiding the management of CPP [98]. The response of PbtO2 to CPP/MAP increase allows the tailoring of the individual CPP threshold [98] [99]. Combined with TCD and neuroimaging, PbtO2 reactivity is adapted to manage delayed cerebral ischaemia in comatose patients with subarachnoid hemorrhage (SAH) when the classical influence factors are $\mathrm{SaO} 2, \mathrm{ScO} 2, \mathrm{PvO} 2$, and haemoglobinaemia, and while moderate hyperventilation [100], protective ventilation [101], and blood transfusion [102] may even be adjusted using PbtO2. Regarding neuro-trauma, a low $\mathrm{PbtO} 2$ without reactivity is a strong marker of poor outcome [103] and a discordant low PbtO2 may occur while ICP and CPP remain within the recommended thresholds [104]. This high intrinsic value has led to the recent incorporation of this topographical parameter into the recommendations for the brain injured patient [105] [106]. The progressive multiple parameter adjustment to increase PbtO2 has even been proposed as a useful way to identify "PbtO2 responders" with a better outcome [107]. However, despite this positive trend, the real impact on patient outcome of PbtO2-directed therapy remains controversial [105] [106] [108] and needs further investigations to clarify the vision. Nevertheless, the clinical relevance, safety, and effective documentation in the literature make the $\mathrm{PbtO} 2$ a quite systematically recommended parameter in routine CNS multimodal monitoring.

\subsection{Cerebral Oximetry (Sct02) Using Near-Infrared Spectrometry (NIRS)}

The measurement of SctO2 using NIRS technology [109]-[111] represents a newer alternative to PtbO2 for the direct measurement of cerebral tissue oxygenation. Different methodologies exist and are commercially availa- 
ble [112]: modified Beer-Lambert law, multidistance or spatially resolved spectroscopy, frequency-resolved (domain) spectroscopy, and time-resolved spectroscopy. Before being used for cerebral oximetry monitoring in anesthesia and in intensive care, NIRS was developed by neuroscientists and neurocognitivists for brain function investigation [113] [114]. Briefly, a rapid change in NIRS, recorded spontaneously or after stimulation, is directly correlated to the variation of function of the neural tissue just below the electrode, based on the "near-infrared window" concept [115] and the event-related evoked optical stimulation (EROS), a suitable and attractive method for the cognitive neurosciences [116].

In this context, NIRS has been topographically used in fundamental research, using relatively complex multiple electrode montages over the skull [117], corresponding to a new category of functional brain mapping, alone or combined with EEG [118], showing the complementarity of these technologies. Alternatively, for the intraoperative period or in the ICU, different dual-channel oximeters simplified for clinical practice (FORESIGHT device, CAS-Medical Systems, Brandford, CT, USA; INVOS series, Somanetics, Troy, MI, USA; and NIRO series, Hamamatsu Photonics K.K., Hamamatsu City, Japan) may be used.

Two electrodes disposed on the forehead of the patient would give information about oxygenation in the right and left cerebral hemispheres. Basically, NIR cerebral oximetry does not rely on pulsatile flow but measures a weighted average of arterial, capillary, and venous compartments (unfortunately, by cumulative assessment) in proportion to their relative intracranial volumes within the field of view [119]. It is measured following different physical methods (regional cerebral saturation by the INVOS series, tissue oxygenation index by the NIRO series, and SctO2 by the FORE-SIGHT device), making sometimes difficult the comparison. For instance, despite normative values of SctO2 of between $60 \%$ and $75 \%$ and a coefficient of variation for absolute baseline values of approximately $10 \%$ [120] being validated for the healthy brain, a wide intra- and inter-individual baseline variability remains a potential problem. The use of NIRS to guide the manipulation of systemic physiology to minimise the risk of cerebral hypoxia/ischaemia during carotid endarteriectomy (CEA) is an area where NIRS needs to be proved to have at least equivalent sensitivity and specificity to the other recommended modalities of monitoring [121]-[123]. NIRS has not been clearly proven to be superior for identifying critical cerebral ischaemia. The body of evidence suggests only a broad equivalence to other modalities, albeit with uncertainty as to the exact NIRS-derived threshold for the identification of critical ischaemia [124]-[126] (low positive predictive value). Regarding cardiac surgery, the absence of compelling data to support the use of NIRS-guided management strategies to reduce the incidence of postoperative cognitive dysfunction and stroke has not prevented NIRS from gaining popularity as a monitoring modality for the management of cerebral oxygenation during cardiac surgery [127] [128], particularly taking in account the significant associated over-cost (electrodes).

However, a recent review suggests that the neurocognitive decline after cardiac bypass surgery may not only be related to the intervention but may also reflect the natural decline of patients with multiple comorbidities raises an important question about the impact and value of neuro-monitoring, including NIRS, to guide treatment during cardiopulmonary bypass [129]. Otherwise, NIRS has been suggested for monitoring the healthy but at-risk brain during routine surgical procedures under general anesthesia, but always without real confirmation [130]. In this context, patients undergoing surgery in the beach chair position could take advantage of SctO2 monitoring. Severe hypotension occurs in up to $20 \%$ of patients [131] and ischaemia-related cerebrovascular events have been reported [132]. It was first reported in an isolated case [133] [134] and then demonstrated by an observational study [135] of shoulder arthroscopy in a beach chair versus lateral decubitus position and using a FORE-SIGHT ${ }^{\mathrm{TM}}$ oximeter, which demonstrated cerebral desaturation in $80 \%$ of patients in the beach chair position compared with none in the lateral decubitus position. Nevertheless, there was no postoperative neurological impact, only a higher incidence of nausea and vomiting, supporting the hypothesis that brain oxygenation might be a surrogate of the adequacy of non-neurological organ perfusion.

Regarding brain injury in the ICU, the complex relationships between NIRS and other physiological variables (ICP, blood flow velocity, etc.) routinely used to assess cerebrovascular reactivity make it necessary to apply more complex analytical techniques to perform qualitative and quantitative analysis of cerebrovascular reactivity that is not available with other methods [136]. This way, NIRS might potentially provide the monitoring of cerebral autoregulation, although this is uncertain at present. However, compared with PbtO2, NIRS lacks power for brain ischaemia detection in neuro-ICU [137]. For now, PbtO2 remains the method of choice, but SctO2 by NIRS is not necessarily inferior. The problem is trying to define the real interest and indications of this userfriendly, noninvasive monitoring modality. With several practical advantages in comparison to other neuro- 
monitoring techniques (invasive or minimally invasive), such as the capability to make measurements over multiple regions of interest simultaneously with high temporal resolution, NIRS might potentially monitor regional cerebral oxygenation, haemodynamics, and metabolism, and could guide therapeutic brain protection strategies. For now, mainly validated when ischemia occurs in normal and healthy brain monitoring without major neurological problem, it seems to suffer from a lack of concrete recommendations for use, bearing in mind that NIRS technology has the potential benefit of multiple recording sites either at the skull level (brain mapping similar to EEG and QEEG) or at extracranial sites for muscular oxygenation and metabolism follow-up [138] [139] or peripheral perfusion [140] [141].

To summarise (Table 7) regarding the three methodological options for brain oxygen monitoring, the maximal interest in $\mathrm{SjVO} 2$ was shown 10 to 15 years ago. It has been progressively replaced by the minimally invasive $\mathrm{PbtO} 2$ monitoring that is now more and more well established in clinical practice, while SctO2 by NIRS has not found its proper place in clinical practice in relation to its intrinsic practical advantages, and truly needs a clearer and objective definition of its recommended uses.

Table 7. The three methodological options regarding cerebral brain oxygen monitoring.

\begin{tabular}{|c|c|c|c|}
\hline & $\begin{array}{l}\text { Jugular venous oxygen } \\
\text { saturation (SjvO2) }\end{array}$ & $\begin{array}{l}\text { Brain tissue oxygen } \\
\text { tension (PbtO2) }\end{array}$ & $\begin{array}{l}\text { Cerebral oximetry using } \\
\text { near-infrared spectrometry } \\
\text { (SctO2 - NIRS) }\end{array}$ \\
\hline $\begin{array}{l}\text { Basic principle } \\
\text {-indicator }\end{array}$ & $\begin{array}{l}\text { Oxygen consumption } \\
\text { —oxygen need-cerebral } \\
\text { metabolism }\end{array}$ & $\begin{array}{l}\text { Oxygen diffusion }> \\
\text { cerebral metabolism }\end{array}$ & $\begin{array}{l}\text { Oxygen consumption-oxygen } \\
\text { need-cerebral metabolism in } \\
\text { normal healthy brain }\end{array}$ \\
\hline Applicability & Continuous at bedside & Continuous at bedside & Continuous at bedside \\
\hline Application fields & Intraoperative ICU & Intraoperative ICU & Intraoperative ICU \\
\hline Device & Invasive & Minimally invasive & Non-invasive (main advantage) \\
\hline Limitations of use & $\begin{array}{l}\text {-Catheter tip displacement } \\
\text {-Compiled hemispheric } \\
\text { measurement } \\
\text {-Lack of detection of } \\
\text { limited ischaemia } \\
\text {-Extracranial blood pollution }\end{array}$ & $\begin{array}{l}\text {-Local or regional measurement } \\
\text {-Site-dependent measurement }\end{array}$ & $\begin{array}{l}\text {-Mainly healthy brain monitoring } \\
\text {-Inter- \& intra-individual variability } \\
\text {-Complex multi-factor brain } \\
\text { pathophysiological process } \\
\text {-Compiled hemispheric measurement } \\
\text {-Desaturation } \neq \text { real ischaemia and } \\
\text { infarction } \\
\text {-Specific SctO2 determination } \\
\text { methodology of each device }\end{array}$ \\
\hline Cost-investment & $\begin{array}{l}\text {-Monitoring } \\
\text {-Probe (reusable or single use) }\end{array}$ & $\begin{array}{l}\text {-Monitoring } \\
\text {-Probe (single use) }\end{array}$ & $\begin{array}{l}\text {-Monitoring } \\
\text {-Probe (single use) }\end{array}$ \\
\hline $\begin{array}{l}\text { Technical expertise, } \\
\text { management \& nursing }\end{array}$ & $\begin{array}{l}\text { Advanced } \\
\text { Time-consuming }\end{array}$ & $\begin{array}{l}\text { Advanced } \\
\text { Time-consuming }\end{array}$ & $\begin{array}{l}\text { Basic } \\
\text { (intuitive) }\end{array}$ \\
\hline $\begin{array}{l}\text { Specific infrastructure } \\
\text { for insertion }\end{array}$ & $\begin{array}{l}\text { Special need } \\
\text { (invasive, ICU, or OR) }\end{array}$ & $\begin{array}{l}\text { Special need } \\
\text { (minimally invasive, OR) }\end{array}$ & No need \\
\hline Ischaemia detection & $\begin{array}{l}\text { Hemispheric } \\
\text { (focal ischaemia undetected) }\end{array}$ & $\begin{array}{l}\text { Local } \\
\text { (insertion site-dependent) }\end{array}$ & Hemispheric \\
\hline CPP correlation & & $\begin{array}{l}\mathrm{CPP}<60 \text { mmHg: } \mathrm{PbtO} 2 \downarrow \\
\mathrm{CPP}>60 \text { mmHg: } \mathrm{PbtO} 2 \approx \text { or } \uparrow\end{array}$ & $\begin{array}{l}\text { Variable } \\
(+/- \text { more specific than SjvO2) }\end{array}$ \\
\hline Numeric values & $\begin{array}{l}\text {-Normal: } 60 \% \text { - } 90 \% \\
\text {-Critical: } 50 \% \text { - 55\% during } \\
15 \text { min = cerebral ischaemia }\end{array}$ & $\begin{array}{l}\text {-Normal: } 25 \text { - } 35 \mathrm{mmHg} \\
\text {-Critical: }<15 \mathrm{mmHg}=\text { ischaemia } \\
\text {-<6 mmHg = infarction, even } \\
\text { cerebral death }\end{array}$ & $\begin{array}{l}\text {-Normal: } 60 \% \text { - } 75 \% \\
\text {-Baseline variation: } 10 \% \\
\text { - } 13 \% \text { : ischaemic threshold } \\
\text {-35\% during } 2 \text { - } 3 \text { h: infarction }\end{array}$ \\
\hline $\begin{array}{l}\text { Thresholds } \\
\text { correspondance }\end{array}$ & $50 \%$ & $8.5 \mathrm{mmHg}$ & $\begin{array}{l}\text { To be determined-variable } \\
\text { (correct for internal carotid } \\
\text { clamping, circulatory arrest) }\end{array}$ \\
\hline
\end{tabular}

ICU: intensive care unit; $\boldsymbol{O R}$ : operating room; $\boldsymbol{C P P}$ : cerebral perfusion pressure. 


\section{Cerebral Blood Perfusion}

\subsection{Regional Cerebral Blood Flow}

PbtO2 (for the physiological definition, see the "Brain tissue oxygen tension" section) represents only an indirect assessment of the CBF influenced by external factors [98]. A recent technological alternative allows the direct measurement of regional blood flow (rCBF) via a thermal diffusion probe (TDP; Hemedex, Cambridge, Massachusetts, USA), giving results in absolute units. This probe may be inserted into the brain parenchyma, close to the ICP/PbtO2 probes (cf. multimodality concept). It can be either tunnelled from the surgical area or directly bolted (stable fixation of the probe through a skull bolt to avoid catheter dislodgement). Similar to $\mathrm{PbtO} 2$, the probe tip provides a quantitative measurement only in the spherical volume of tissue surrounding the sensor. The TDP technology was first successfully validated by comparing the rCBF measurements with the xenonCT [142]. Insertion of the probe $2.5 \mathrm{~cm}$ below the dura in the white matter is checked using a CTscan. Otherwise, for the rCBF assessment, the TDP remains dependent on a stable patient temperature trend. Severe hyperthermia and the patient's temperature instability significantly affect the rCBF numerical value.

In brain injured patients (subarachnoid haemorrhage, trauma, etc.), the TDP combined withPbtO2 seems very relevant for optimising CPP management [143] [144]. The results suggest that rCBF-guided MAP/CPP increase could efficiently replace the classical "triple-H" therapy. The main problem remains to define the most judicious site of insertion of the electrode [145]-[147]. Placed at a good site, rCBF allows the assessment of cerebrovascular reactivity to $\mathrm{PaCO} 2$ variations, which is greatly useful for driving moderate hyperventilation, particularly in patients with at least partially altered cerebral autoregulation [148] [149].

Less advanced than $\mathrm{PbtO} 2$ technology in its systematic integration into multimodal neuro-monitoring, rCBF could progressively take a part after, of course, the confirmation of its validity and its implementation in a large population of neurological patients.

\subsection{Local CBF}

For the continuous measurement of CBF at the patient's bedside, Laser Doppler Flowmetry (LDF)represents an old but efficient alternative. The Oxylab LDF system(Oxford Optronix, Abingdon, UK) measures red blood cell movements within the microcirculation only $1 \mathrm{~cm}$ below the dural surface [150] [151], using several possible local devices (surface angular, needle and micro-needle, and endoscope). The physical principle is to invest a smallvolume of cerebral matter (limited to the cortex), but with the highest possible spatial resolution. This is why the LDF does not qualify as regional CBF monitoring but only as local CBF monitoring and is, till now, mainly used in laboratories for fundamental neuro-investigations in small animals (rats, gerbils, rabbits, or cats), for which it is currently a sort of gold standard. However, the LDF has been investigated for use in neurosurgery for a long time, with satisfactory results regarding the early detection of ischaemia and treatment guidance and adjustment [152]-[155], but a possible significant and beneficial impact on patient outcome was never proved. On the other hand, some authors have considered the mapped multi-insertion of LDF probes as a solution to the problem of the limited volume of investigated cerebral matter, at the main condition to select as judiciously as possible the different probe insertion sites. However, this has never been reported in clinical practice. On the other hand, the LDF has been proved to monitor efficiently local spinal cord blood flow in one animal model [156]. Unfortunately, no consistent comparative data have been published on local CBF monitoring using LDF and rCBF, followed up with TDP. However, in a recent article, LDF seems to be logically more sensitive than TCD in detecting cortical autoregulation disturbance during rising ICP and falling CPP in the area of distribution of the middle cerebral artery [157]. This lack of clinical results makes it quite impossible to have a definitive overview and is a little frustrating.

\subsection{TCD, Microvascular Doppler, and Cerebral Tissue Doppler}

Today, TCD is a full element of CNS monitoring despite its limited metabolic and functional dimension, being completely indirect. With the constant and even growing interest in this technology, it is regularly upgraded [158]. In fact, except rCBF and local CBF monitoring, TCD provides the only Foods and Drugs Administration-cleared method to continuously and directly monitor change in cerebral haemodynamics, mainly in perioperative and critical care settings, to give clinically valuable and potentially life-saving information [159] [160]. The technology evolution gives the operator the opportunity of more and more substantial morphological infor- 
mation's [161] about the cerebral vasculature. However, the quality of this monitoring is heavily influenced by the training, skill, experience, and practice of the sonographer. Beside TCD, microvascular Doppler ultrasonography [162] is the only dedicated intraoperative to the check of vascular neurosurgery (aneurysm clipping, vascular bypass of giant aneurysm or arteriovenous malformation, etc.) as a potentially powerful alternative to fluorescein angiography, since the Doppler technology is able to give not only qualitative but also quantitative information. Additionally, it is increasing thought that Doppler technology can be used not only to monitor cerebral vessels but also brain parenchyma, where it would probably be very informative about CBF in a less limited area than the two other methods.

To summarise regarding CBF monitoring methods (Table 8), TCD has advantages with possible evolutions and improvements, may be completed by the assessment of tissue blood flow by Doppler. This sort of a multimodal Doppler tool could be very valuable and powerful. In the meantime, the more limited (local or regional) methods of monitoring of CBF remain of interest, but what can be done with them and for which types of patients have not been clearly defined.

\section{Conclusions}

To conclude, I would like to first list some key learning points that form the foundation of efficient neuromonitoring:

Table 8. The three methodological options regarding cerebral blood flow (CBF) monitoring.

\begin{tabular}{|c|c|c|c|}
\hline & $\begin{array}{l}\text { Regional CBF (rCBF) Thermal } \\
\text { Diffusion Probe (TDP) }\end{array}$ & $\begin{array}{c}\text { Local CBF (ICBF) Laser Doppler } \\
\text { Flowmetry (LDF) }\end{array}$ & $\begin{array}{c}\text { Transcranial Doppler } \\
\text { (TCD) }\end{array}$ \\
\hline $\begin{array}{l}\text { Basic principle } \\
\text {-indicator }\end{array}$ & $\begin{array}{l}\text { Thermal diffusion in a spherical } \\
\text { volume around the tip of the probe }\end{array}$ & $\begin{array}{l}\text { Red blood cell movement within the } \\
\text { microcirculation beside the probe }\end{array}$ & $\begin{array}{l}\text { Major vascular Doppler effect } \\
\text { coupled with two-dimensional } \\
\text { ultrasonography }\end{array}$ \\
\hline Applicability & Continuous at bedside & Continuous at bedside & Continuous at bedside \\
\hline Application fields & $\begin{array}{l}\text { Intraoperative (to be developed) } \\
\text { ICU }\end{array}$ & $\begin{array}{l}\text { Intraoperative (to be re-evaluated } \\
\text { and developed) ICU }\end{array}$ & Intraoperative ICU \\
\hline Device & $\begin{array}{l}\text { Minimally invasive } \\
\text { ( } 2-2.5 \mathrm{~cm} \text { below the dura) }\end{array}$ & $\begin{array}{l}\text { Minimally invasive } \\
\text { (1cm below the dura) }\end{array}$ & Non-invasive (main advantage) \\
\hline Limitations of use & $\begin{array}{l}\text {-Measurement and monitoring } \\
\text { of rCBF only in the spherical area } \\
\text { ( } 1-1.5 \mathrm{~cm} \text { diameter) around the } \\
\text { probe tip } \\
\text {-Site-dependent measurement }\end{array}$ & $\begin{array}{l}\text {-Measurement and monitoring of } \\
\text { lCBF only in the } 1 \text { or } 2 \mathrm{~mm} \\
\text { surrounding the probe tip } \\
\text {-Site-dependent measurement }\end{array}$ & $\begin{array}{l}\text {-Arterial CBF in medium size } \\
\text { vessels (MCA > ACA > PCA) } \\
\text {-Not tissue monitoring } \\
\text {-Possible instability of the probe }\end{array}$ \\
\hline Cost-investment & $\begin{array}{l}\text {-Monitoring } \\
\text {-Probe (single use) }\end{array}$ & $\begin{array}{l}\text {-Monitoring } \\
\text {-Probe (single use) }\end{array}$ & $\begin{array}{l}\text {-Monitoring } \\
\text {-Probe (reusable) } \\
\text {-Fixation system for probes }\end{array}$ \\
\hline $\begin{array}{l}\text { Technical expertise, } \\
\text { management \& nursing }\end{array}$ & Basic Time-consuming & Basic Time-consuming & Advanced \\
\hline $\begin{array}{l}\text { Specific infrastructure } \\
\text { for insertion }\end{array}$ & $\begin{array}{l}\text { Special need } \\
\text { (minimally invasive, ICU, or OR) } \\
\text { Probe tunneled or bolted }\end{array}$ & $\begin{array}{l}\text { Special need } \\
\text { (minimal invasive, ICU or OR) } \\
\text { Probe tunnelled or bolted }\end{array}$ & No need \\
\hline Ischaemia detection & $\begin{array}{l}\text { Local or regional } \\
\text { Cortical and subcortical } \\
\text { (following the insertion's adequacy) }\end{array}$ & $\begin{array}{l}\text { Local Cortical } \\
\text { (following the insertion's } \\
\text { adequacy) }\end{array}$ & Hemispheric or global \\
\hline CPP correlation & Vasoreactivity and autoregulation & Vasoreactivity and autoregulation & $\begin{array}{l}\text { Variable Vasoreactivity and } \\
\text { autoregulation }\end{array}$ \\
\hline Numeric values & -Normal: $40-70 \mathrm{~mL} \cdot 100^{-1} \cdot \mathrm{min}^{-1}$ & $\begin{array}{l}\text {-Normal: } 80 \mathrm{~mL} \cdot 100^{-1} \cdot \mathrm{min}^{-1} \\
\text { (temporo-sylvian cortex) and } \\
60-65 \mathrm{~mL} \cdot 100^{-1} \cdot \mathrm{min}^{-1} \\
\text { (fronto-latero-dorsal cortex) }\end{array}$ & $\begin{array}{l}\text {-Normal: } 30-80 \mathrm{~mL} \cdot 100^{-1} \cdot \mathrm{min}^{-1} \\
\text { Following the artery and based } \\
\text { on the velocity assessment }\end{array}$ \\
\hline
\end{tabular}

MCA: middle cerebral artery; ACA: anterior cerebral artery; PCA: posterior cerebral artery; ICU: intensive care unit; $\boldsymbol{O R}$ : operating room; $\boldsymbol{C P P}$ : cerebral perfusion pressure. 
Table 9. Proposal about the potential multimodal combinations of neuro-parameters of advanced neuro-monitoring in the near future for the intraoperative and/or intensive care unit settings (based on the scientific literature reflecting the actual worldwide practice and on my own practice). For each clinical situation, two to three technologies can be combined. Dark grey indicates validated usual and recommended elements of monitoring. Medium grey indicates parameters with a high level of evidence (equivalent to a recommendation or quite equivalent) In this case; there is consistent scientific literature to support making these parameters probably recommended in the next years. Light grey indicates parameters that require clinical investigations to try to define or to refine the real value. For these, clinical recommendations remain unclear and only potential. Very light grey (regional cerebral blood flow [rCBF] column) is just to point out that rCBF by TDP could be an alternative (or a second choice) to ICBF by LDF that is preferred because of the smallness of the probe.

\begin{tabular}{|c|c|c|c|c|c|c|c|c|c|}
\hline & $\mathbf{E E G}^{\ddagger}$ & EP & MCD & SvjO2 & PbtO2 & $\begin{array}{l}\text { SctO2 } \\
\text { (NIRS) }\end{array}$ & $\begin{array}{l}\text { rCBF } \\
\text { (TDP) }\end{array}$ & $\begin{array}{l}\text { ICBF } \\
\text { (LDF) }\end{array}$ & TCD \\
\hline \multicolumn{10}{|l|}{ Intraoperative neuromonitoring } \\
\hline \multicolumn{10}{|l|}{ 1. Neurosurgery } \\
\hline Invasive spine or spinal cord surgery & & SEP/MEP & & & & & & & \\
\hline $\begin{array}{l}\text { Deep or intermediate hypothermia for brain } \\
\text { vascular neurosurgery }\end{array}$ & & $\begin{array}{l}\text { SEP/VEP } \\
\text { AEP }\end{array}$ & & & & & & & \\
\hline Normothermic brain vascular neurosurgery & & $\begin{array}{l}\text { SEP/VEP } \\
\text { AEP }\end{array}$ & & & & & & & \\
\hline \multicolumn{10}{|l|}{$\begin{array}{l}\text { Cortical brain tumour resection } \\
\text { (meningioma and astrocytoma) }\end{array}$} \\
\hline Posterior fossa surgery* & & SEP/AEP & & & & & & & \\
\hline \multicolumn{10}{|l|}{ Epilepsy surgery** } \\
\hline \multicolumn{10}{|l|}{ Awake surgery*** } \\
\hline $\begin{array}{l}\text { Optic nerve, hypothalamic, pituitary gland, } \\
\text { and diaphragma sellae surgery**** }\end{array}$ & & VEP & & & & & & & \\
\hline Surgical peripheral nerve release & & SEP/MEP & & & & & & & \\
\hline
\end{tabular}

\section{Cardiac \& vascular surgery}

Normothermic thoracic and thoracoabdominal aortic surgery

Normothermic cardiac or vascular surgery

Intermediate hypothermia for cardiac or vascular surgery

Deep hypothermia for cardiac or vascular surgery ${ }^{\S}$

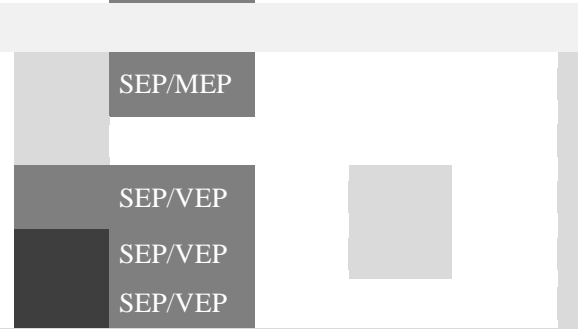

Carotid endarterectomy

SEP/VEP

\section{Intensive care unit}

Post-anoxic coma

Hypothermic coma

Intoxication and poisoning

Brain death

Non-epileptic seizures

Status epilepticus

Subarachnoid haemorrhage

Stroke (acute phase)

Trauma brain injury

Trauma spinal cord injury

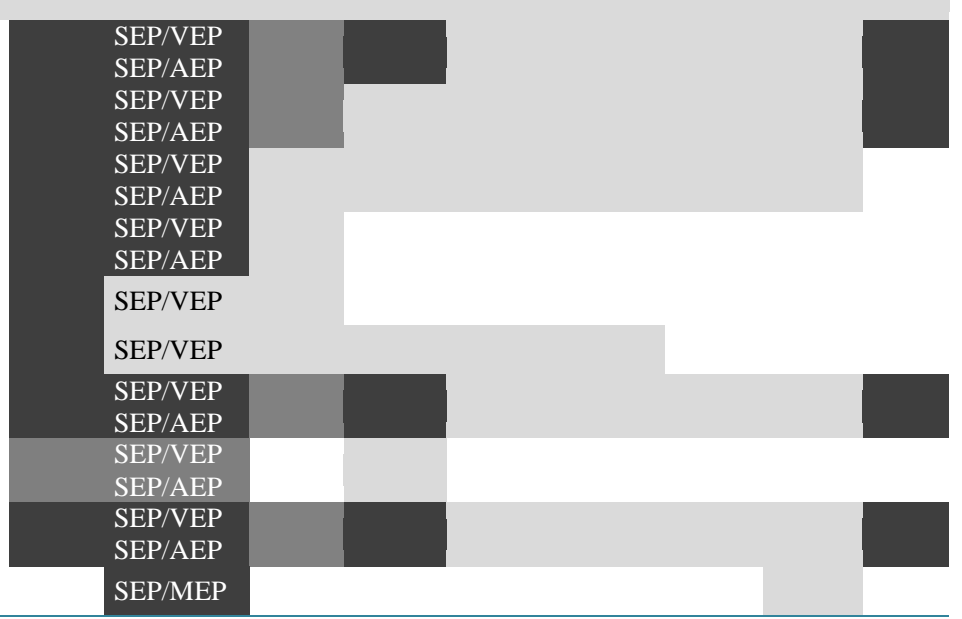

łincluding quantitative EEG (QEEG) but not necessarily simplified forehead EEG-derived technologies; *including intra- and extracranial surgery of the auditory and/or facial nerves; **including surgical lobectomies and other resections, electrocorticography and stereo-EEG electrodes insertion, and intraoperative cortical stimulation; ***including fully awake procedures and asleep-awake-asleep procedures; ****including open and/or endonasal approaches; ' including therapeutic and deliberate cardiac arrest; $\boldsymbol{r C B F}$ : regional cerebral blood flow; TDP: thermal diffusion probe; $\boldsymbol{I C B F}$ : local cerebral blood flow; LDF: laser Doppler flowmetry; EEG: electroencephalogram; EP: evoked potentials; MCD: microdialysis; SvjO2: jugular venous oxygen saturation; PbtO2: brain tissue oxygen tension; SctO2: Cerebral oximetry using near infrared spectrometry; TCD: transcranial Doppler. 
1) The variability of CNS metabolism and function is typical of the different anesthetic phases and in comatose patients. Influenced by physiological and pathophysiological factors, one of our main challenges is to impact it as efficiently as possible.

2) Regarding CNS metabolism and function monitoring, a minimal subdivision has to be respected: the cerebral cortex and deeper structures as interdependent entities, each with a high level of differentiation and complexity.

3) The different cerebral cortical areas are dedicated to different functions and their pharmacological and pathophysiological sensitivity is not similar orhomogeneous. This underlies the concept of topographical investigations for mapping.

4) Regarding not only the electrical signals of the CNS but also the other specialized neuro-monitoring modalities, they potentially have dual dimensions: basic spontaneous activities and advanced evoked responses.

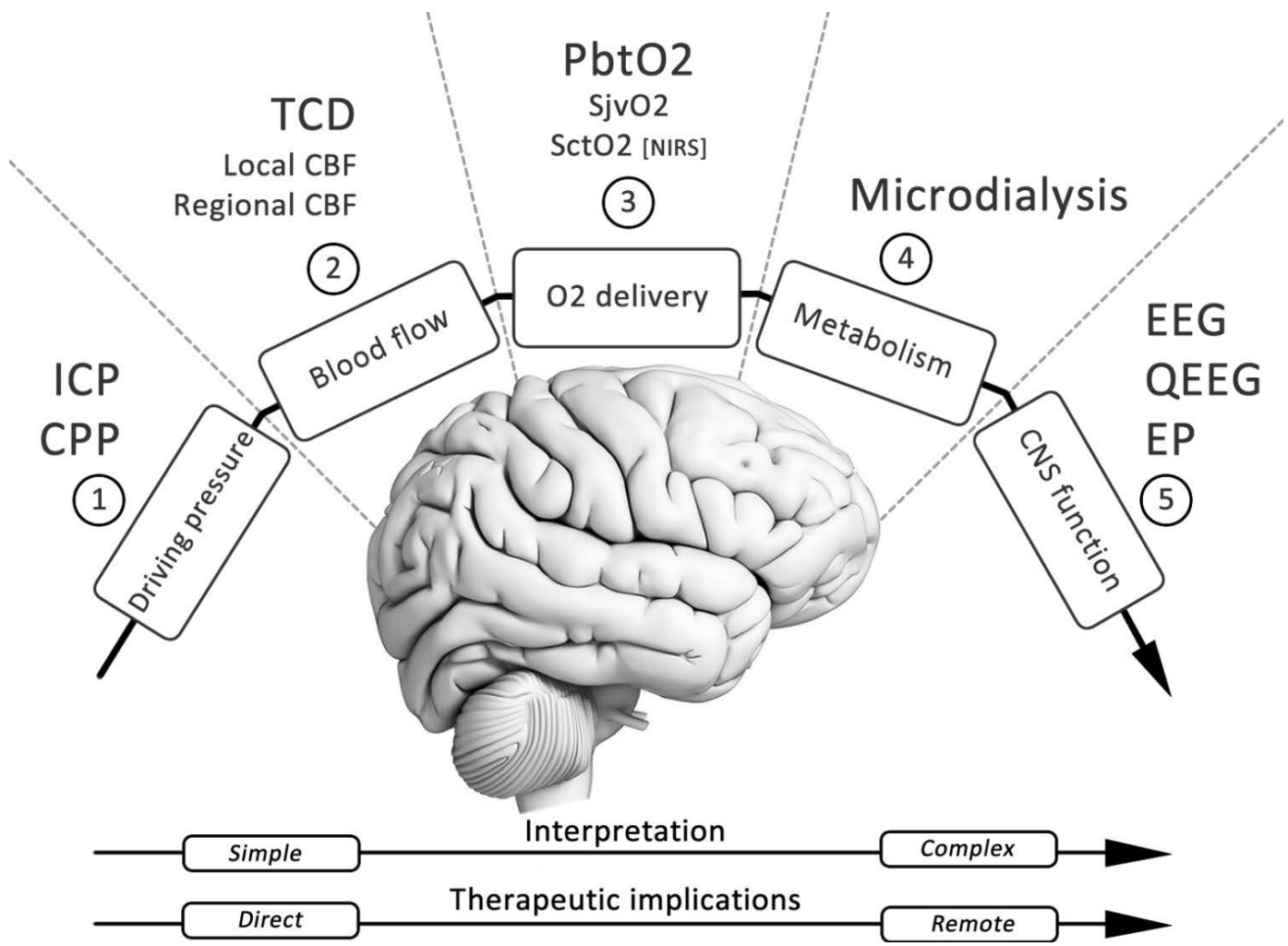

Figure 1. Do we need a more advanced brain and spinal cord monitoring to follow metabolism and function? To make more concrete the multimodal approach, it is possible to put in accordance the different possible modalities of CNS monitoring to the respective level in the phenomenological chain leading to the highest complexity: the CNS function and neurons functioning, on right. First, the driving pressure method is based on the usual and continuous monitoring of the ICP and CPP. Second, about CBF assessment, the TCD remains the reference technique even if local CBF (lCBF) or regional CBF (rCBF) would deserve to be considered a new time. Third, to follow the 02 delivery, the PbtO2 has progressively supplanted the classical SjvO2, without to be really competed with the cerebral oximetry, remaining an $\mathrm{O} 2$ cerebral diffusion indicator rather than a really metabolic parameter. Fourth, the metabolism is essentially related by the microdialysis technique for which an increased glutamate, a high lactate/pyruvate ratio with a low glucose in the brain relate a CNS cellular hypoxia. Finally, in point 5 , the electrophysiology is alone able to give an idea of the CNS function and neurons functioning. About the phenomenological chain from point 1 to point 5 , each item is required for the further factors downstream as in a sort of cascade. The corresponding monitoring items progress from the most basic (on left) with the simplest interpretation to the most advanced (on right) with more complex results sometime difficult to put in perspective with the patient situation. Similarly, the impact on the patients' treatment varies from direct to remote or indirect. However, the level of the accuracy of the information's given by the successive monitoring's is progressively growing up, counterbalancing the apparent awkwardness of use. The investment of time to know how to use the different modalities of this monitoring would be always very productive and beneficial either for the clinicians or particularly for the patients. 
5) Multimodality, which is more and more recommended in practice, has to try to define the most judicious combination of parameters from different origins (electrical, oxygen consumption and supply, and blood perfusion and supply) to give the best possible answer for the specific patient's situation.

6) Electrophysiology (EEG, QEEG, and evoked potentials) represents a cornerstone but remains underused because of the absolute need for education.

7) Regarding brain oxygen monitoring, $\mathrm{PbtO} 2$ has now supplanted $\mathrm{SjvO} 2$ and represents the reference technology. As for SctO2 by NIRS, it is still controversial and we have to wait some more years for definite and strict recommendations for use.

8) Regarding cerebral perfusion, rCBF is interesting but is, unfortunately, too site-dependent to be sufficient. LDF has to be re-evaluated in clinical practice to refine its real interest, specificity and sensitivity. This is the only one with a specific potential interest about spinal cord blood flow monitoring owing to the smallness of its probe.

Finally, regarding brain and spinal cord metabolism and function, continual developments in monitoring methods provide more and more valuable information and more and more accurate answers to questions about potential problems. As to what is called "multimodality" and within the available technologies listed in this article, someone's, older, are more investigated and evaluated in clinical practice and others, more recent are still waiting to find their respective position in the neuro-monitoring arsenal. Far from excluding any technology, the best remains to learn and to know as much as possible what they are and what we can expect of them, to limit the risk of misuse and misevaluation. The development of a real effective neuro-monitoring, combining one monitoring modality of each family (electrophysiology, microdialysis, brain oxygen, and CBF) could be the final solution (Table 9). To make more concrete this sort of methodic approach, it is also possible to classify the different modalities according the level in the phenomenological chain leading to the highest step of complexity: the brain or spinal cord function (Figure 1). For now, this idea remains only conceptual but this is our role for the next years, to drive investigations to have the opportunity to justify the usefulness of this second generation neuro-monitoring.

\section{References}

[1] Sebel, P. and Fitch, W. (1994) Monitoring the Central Nervous System. Blackwell Science, London, 479.

[2] Grundy, B.L. (1982) Monitoring of Sensory Evoked Potentials during Neurosurgical Operations: Methods and Applications. Neurosurgery, 11, 556-575. http://dx.doi.org/10.1227/00006123-198210000-00020

[3] Grundy, B.L. (1983) Intraoperative Monitoring of Sensory-Evoked Potentials Anesthesiology, 58, $72-87$. http://dx.doi.org/10.1097/00000542-198301000-00011

[4] Grundy, B.L. (1984) Evoked Potentials in the Operating Rooms. Mount Sinai Journal of Medicine, 51, 585-591.

[5] Thornton, C., Catley, D.M., Jordan, C., Lehane, J.R., Royston, D. and Jones, J.G. (1983) Enflurane Anaesthesia Causes Graded Changes in the Brainstem and the Early Cortical Auditory Evoked Response in Man. British Journal of Anaesthesia, 55, 479-486. http://dx.doi.org/10.1093/bja/55.6.479

[6] Thornton, C., Heneghan, C.P., James, M.F. and Jones, J.G. (1984) Effects of Halothane or Enflurane with Controlled Ventilation on Auditory Evoked Potentials. British Journal of Anaesthesia, 56, 315-323. http://dx.doi.org/10.1093/bja/56.4.315

[7] Lee, S.H. and Dan, Y. (2012) Neuromodulation of Brain States. Neuron, 76, 209-222. http://dx.doi.org/10.1016/j.neuron.2012.09.012

[8] Pandin, P. and Dewitte, O. (2007) Open Low-Field Intraoperative MRI for Transsphenoidal Pituitary Surgery. Anesthesia \& Analgesia, 105, 886. http://dx.doi.org/10.1213/01.ane.0000268558.02855.73

[9] Vespa, P. (2005) Continuous EEG Monitoring for the Detection of Seizures in Traumatic Brain Injury, Infarction, and Intracerebral Hemorrhage: “To Detect and Protect”. Journal of Clinical Neurophysiology, 22, 99-106. http://dx.doi.org/10.1097/01.WNP.0000154919.54202.E0

[10] Vespa, P. (2005) Multimodality Monitoring and Telemonitoring in Neurocritical Care: From Microdialysis to Robotic Telepresence. Current Opinion in Critical Care, 11, 133-138. http://dx.doi.org/10.1097/01.ccx.0000155353.01489.58

[11] Guérit, J.M., Amantini, A., Amodio, P., Andersen, K.V., Butler, S., de Weerd, A., et al. (2009) Consensus on the Use of Neurophysiological Tests in the Intensive Care Unit (ICU): Electroencephalogram (EEG), Evoked Potentials (EP), and Electroneuromyography (ENMG). Clinical Neurophysiology, 39, 71-83. http://dx.doi.org/10.1016/j.neucli.2009.03.002

[12] Kurtz, P., Hanafy, K.A. and Claassen, J. (2009) Continuous EEG Monitoring: Is It Ready for Prime Time? Current 
Opinion in Critical Care, 15, 99-109. http://dx.doi.org/10.1097/MCC.0b013e3283294947

[13] Tamaki, T. and Kubota, S. (2007) History of the Development of Intraoperative Spinal Cord Monitoring. European Spine Journal, 16, S140-S146. http://dx.doi.org/10.1007/s00586-007-0416-9

[14] Nash Jr., C.L., Lorig, R.A., Schatzinger, L.A. and Brown, R.H. (1977) Spinal Cord Monitoring during Operative Treatment of the Spine. Clinical Orthopaedics and Related Research, 126, 100-105.

[15] Coles, J.G., Wilson, G.J., Sima, A.F., Klement, P. and Tait, G.A. (1982) Intraoperative Detection of Spinal Cord Ischemia Using Somatosensory Cortical Evoked Potentials during Thoracic Aortic Occlusion. The Annals of Thoracic Surgery, 34, 299-306. http://dx.doi.org/10.1016/S0003-4975(10)62499-X

[16] Oddo, M., Villa, F. and Citerio, G. (2012) Brain Multimodality Monitoring: An Update. Current Opinion in Critical Care, 18, 111-118. http://dx.doi.org/10.1016/S0003-4975(10)62499-X

[17] Grocott, H.P., Davie, S. and Fedorow, C. (2010) Monitoring of Brain Function in Anesthesia and Intensive Care. Current Opinion in Anaesthesiology, 23, 759-764. http://dx.doi.org/10.1097/ACO.0b013e3283404641

[18] John, E.R. (2002) The Neurophysics of Consciousness. Brain Research Reviews, 39, 1-28. http://dx.doi.org/10.1016/S0165-0173(02)00142-X

[19] John, E.R. and Prichep, L.S. (2005) The Anesthetic Cascade: A Theory of How Anesthesia Suppresses Consciousness. Anesthesiology, 102, 447-471. http://dx.doi.org/10.1097/00000542-200502000-00030

[20] John, E.R. and Prichep, L.S. (2006) The Relevance of QEEG to the Evaluation of Behavioral Disorders and Pharmacological Interventions. Clinical EEG and Neuroscience, 37, 135-143. http://dx.doi.org/10.1177/155005940603700210

[21] Nuwer, M.R. (1994) Electroencephalograms and Evoked Potentials. Monitoring Cerebral Function in the Neurosurgical intensive Care Unit. Neurosurgery Clinics of North America, 5, 647-659.

[22] Nuwer, M. (1997) Assessment of Digital EEG, Quantitative EEG, and EEG Brain Mapping: Report of the American Academy of Neurology and the American Clinical Neurophysiology Society. Neurology, 49, 277-292. http://dx.doi.org/10.1212/WNL.49.1.277

[23] Nuwer, M.R. (2007) ICU EEG Monitoring: Nonconvulsive Seizures, Nomenclature, and Pathophysiology. Clinical Neurophysiology, 118, 1653-1654. http://dx.doi.org/10.1016/j.clinph.2007.01.026

[24] Kochs, E., Bischoff, P., Pichlmeier, U. and Esch, S.J. (1994) Surgical Stimulation Induces Changes in Brain Electrical Activity during Isoflurane/Nitrous Oxide Anesthesia. A Topographic Electroencephalographic Analysis. Anesthesiology, 80, 1026-1034. http://dx.doi.org/10.1097/00000542-199405000-00012

[25] Pandin, P., Van Cutsem, N., Tuna, T. and D’hollander, A. (2006) Bispectral Index Is a Topographically Dependent Variable in Patients Receiving Propofol Anaesthesia. British Journal of Anaesthesia, 97, 676-680. http://dx.doi.org/10.1093/bja/ael235

[26] Rampil, I. (1998) A Primer for EEG Signal Processing in Anesthesia. Anesthesiology, 89, 980-1002. http://dx.doi.org/10.1097/00000542-199810000-00023

[27] Jameson, L.C. and Sloan, T.B. (2006) Using EEG to Monitor Anesthesia Drug Effects during Surgery. Journal of Clinical Monitoring and Computing, 20, 445-472. http://dx.doi.org/10.1007/s10877-006-9044-x

[28] Jameson, L.C. and Sloan, T.B. (2012) Neurophysiologic Monitoring in Neurosurgery. Anesthesiology Clinics, 30, 311331. http://dx.doi.org/10.1016/j.anclin.2012.05.005

[29] Jäntti, V. and Yli-Hankala, A. (2000) Neurophysiology of Anaesthesia. Supplements to Clinical Neurophysiology, 53, 84-88. http://dx.doi.org/10.1016/S1567-424X(09)70142-4

[30] Guérit, J.M. (2000) The Usefulness of EEG, Exogeneous Evoked Potentials and Cognitive Evoked Potentials in the Acute Stage of Post-Anoxic and Post-Traumatic Coma. Acta Neurologica Belgica, 100, 229-236.

[31] Sloan, T.B. (1995) Electrophysiologic Monitoring in Head Injury. New Horizons, 3, 431-438.

[32] Vato, A., Bonzano, L., Chiappalone, M., Cicero, S., Morabito, F., Novellino, A., et al. (2004) Spike Manager: A New Tool for Spontaneous and Evoked Neuronal Networks Activity Characterization. Neurocomputing, 58-60, 1153-1161. http://dx.doi.org/10.1016/j.neucom.2004.01.180

[33] Pasternak, J.J. and Lanier, W.L. (2012) Neuroanesthesiology Update. Journal of Neurosurgical Anesthesiology, 24, 85112. http://dx.doi.org/10.1097/ANA.0b013e31824a8152

[34] Bratton, S.L., Chestnut, R.M., Ghajar, J., Hammond, F.F.M., Harris, O.A., Hartl, R., et al. (2007) Guidelines for the Management of Severe Traumatic Brain Injury. VI. Indications for Intracranial Pressure Monitoring. Journal of Neurotrauma, 24, S37-S44. http://dx.doi.org/10.1089/neu.2007.9990

[35] Andrews, P.J. and Citerio, G. (2004) Intracranial Pressure. Part One: Historical Overview and Basic Concepts. Intensive Care Medicine, 30, 1730-1733.

[36] Citerio, G. and Andrews, P.J. (2004) Intracranial Pressure. Part Two: Clinical Applications and Technology. Intensive 
Care Medicine, 30, 1882-1885. http://dx.doi.org/10.1007/s00134-004-2377-3

[37] Mokri, B. (2001) The Monro-Kellie Hypothesis. Neurology, 56, 1746-1748. http://dx.doi.org/10.1212/WNL.56.12.1746

[38] Treggiari, M.M., Schutz, N., Yanez, N.D. and Romand, J.A. (2007) Role of Intracranial Pressure Values and Patterns in Predicting Outcome in Traumatic Brain Injury: A Systematic Review. Neurocritical Care, 6, 104-112. http://dx.doi.org/10.1007/s12028-007-0012-1

[39] Kirkman, M.A. and Smith, M. (2014) Intracranial Pressure Monitoring, Cerebral Perfusion Pressure Estimation, and ICP/CPP-Guided Therapy: A Standard of Care or Optional Extra after Brain Injury? British Journal of Anaesthesia, 112, 35-46. http://dx.doi.org/10.1093/bja/aet418

[40] Chesnut, R.M., Tembin, N., Carney, N., Dikmen, S., Rondina, C., Videtta, W., et al. (2012) A Trial of Intracranial-Pressure Monitoring in Traumatic Brain Injury. The New England Journal of Medicine, 367, 2471-2481. http://dx.doi.org/10.1056/NEJMoa1207363

[41] Kristiansson, H., Nissborg, E., Bartek, J., Andresen, M., Reinstrup, P. and Romner, B. (2013) Measuring Elevated Intracranial Pressure through Noninvasive Methods: A Review of the Literature. Journal of Neurosurgical Anesthesiology, 25, 372-385. http://dx.doi.org/10.1097/ANA.0b013e31829795ce

[42] Manwaring, P.K., Moodie, K.L., Hartov, A., Manwaring, K.H. and Halter, R.J. (2013) Intracranial Electrical Impedance Tomography: A Method of Continuous Monitoring in an Animal Model of Head Trauma. Anesthesia \& Analgesi, 117, 866-875. http://dx.doi.org/10.1213/ANE.0b013e318290c7b7

[43] Bouzat, P., Francony, G., Fauvage, B. and Payen, J.F. (2010) Transcranial Doppler Pulsatility Index for Initial Management of Brain-Injured Patients. Neurosurgery, 67, E1863-E1864. http://dx.doi.org/10.1227/NEU.0b013e3181f932e7

[44] Rajajee, V., Vanaman, M., Fletcher, J.J. and Jacobs, T.L. (2011) Optic Nerve Ultrasound for the Detection of Raised Intracranial Pressure. Neurocritical Care, 15, 506-515. http://dx.doi.org/10.1007/s12028-011-9606-8

[45] Dubost, C., Le Gouez, A., Jouffroy, V., Roger-Christoph, S., Benhamou, D., Mercier, F.J., et al. (2012) Optic Nerve Sheath Diameter Used as Ultrasonographic Assessment of the Incidence of Raised Intracranial Pressure in Preeclampsia: A Pilot Study. Anesthesiology, 116, 1066-1071. http://dx.doi.org/10.1097/ALN.0b013e318246ea1a

[46] Voss, S.E., Horton, N.J., Tabucchi, T.H., Folowosele, F.O. and Shera, C.A. (2006) Posture-Indiced Changes in Distorsion-Product Otoacoustic Emissions and the Potential for Noninvasive Monitoring of Intracranial Pressure. Neurocritical Care, 4, 251-257. http://dx.doi.org/10.1385/NCC:4:3:251

[47] Lin, A.P., Liao, H.J., Merugumala, S.K., Prabhu, S.P., Meehan, W.P. and Ross, B.D. (2012) Metabolic Imaging of Mild Traumatic Brain Injury. Brain Imaging and Behavior, 6, 208-223. http://dx.doi.org/10.1007/s11682-012-9181-4

[48] Stam, C.J. and van Straaten, E.C. (2012) The Organization of Physiological Brain Networks. Clinical Neurophysiology, 123, 1067-1087. http://dx.doi.org/10.1016/j.clinph.2012.01.011

[49] Pandin P. (2004) The Neuro-Anaesthesiology Assisted by the Electroencephalogram. Annales Françaises d'Anesthésie et de Réanimation, 23, 395-403. http://dx.doi.org/10.1016/j.annfar.2004.01.006

[50] Abend, N.S., Dlugos, D.J., Hahn, C.D., Hirsch, L.J. and Herman, S.T. (2010) Use of EEG Monitoring and Management of Nonconvulsive Seizures in Critically Ill Patients: A Survey of Neurologists. Neurocritical Care, 12, 382-389. http://dx.doi.org/10.1007/s12028-010-9337-2

[51] Rossetti, A.O. and Oddo, M. (2010) The Neuro-ICU Patient and Electroencephalography Paroxysms: If and When to Treat. Current Opinion in Critical Care, 16, 105-109. http://dx.doi.org/10.1097/MCC.0b013e3283374b5b

[52] Vespa, P.M., Miller, C., McArthur, D., Eliseo, M., Etchepare, M., Hirt, D., et al. (2007) Nonconvulsive Electrographic Seizures after Traumatic Brain Injury Result in a Delayed, Prolonged Increase in Intracranial Pressure and Metabolic Crisis. Critical Care Medicine, 35, 2830-2836. http://dx.doi.org/10.1097/01.CCM.0000295667.66853.BC

[53] Vespa, P.M., McArthur, D.L., Xu, Y., Eliseo, M., Etchepare, M., Dinov, I., et al. (2010) Nonconvulsive Seizures after Traumatic Brain Injury ARE Associated with Hippocampal Atrophy. Neurology, 75, 792-798. http://dx.doi.org/10.1212/WNL.0b013e3181f07334

[54] Friedman, D., Claassen, J. and Hirsch, L.J. (2009) Continuous Electroencephalogram Monitoring in the Intensive Care Unit. Anesthesia \& Analgesia, 109, 506-523. http://dx.doi.org/10.1213/ane.0b013e3181a9d8b5

[55] Olivecrona, M., Zetterlund, B., Rodling-Wahlström, M., Naredi, S. and Koskinen, L.O.D. (2009) Absence of Electroencephalographic Seizure Activity in Patients Treated for Head Injury with an Intracranial Pressure-Targeted Therapy. Journal of Neurosurgery, 110, 300-305. http://dx.doi.org/10.3171/2008.4.17538

[56] Naidech, A.M., Garg, R.K., Liebling, S., Levasseur, K., Macken, M.P., Schuele, S.U., et al. (2009) Anticonvulsant Use and Outcomes after Intracerebral Hemorrhage. Stroke, 40, 3810-3815. http://dx.doi.org/10.1161/STROKEAHA.109.559948

[57] Claassen, J., Hirsch, L.J., Kreiter, K.T., Du, E.Y., Connolly, E.S., Emerson, R.G., et al. (2004) Quantitative Conti- 
nuous EEG for Detecting Delayed Cerebral Ischemia in patients with Poor-Grade Subarachnoid Hemorrhage. Clinical Neurophysiology, 115, 2699-2710. http://dx.doi.org/10.1016/j.clinph.2004.06.017

[58] Rathakrishnan, R., Gotman, J., Dubeau, F. and Angle, M. (2011) Using Continuous Electroencephalography in the Management of Delayed Cerebral Ischemia Following Subarachnoid Hemorrhage. Neurocritical Care, 14, 152-161. http://dx.doi.org/10.1007/s12028-010-9495-2

[59] Diedler, J., Sykora, M., Bast, T., Poli, S., Veltkamp, R., Mellado, P., et al. (2009) Quantitative EEG Correlates of Low Cerebral Perfusion in Severe Stroke. Neurocritical Care, 11, 210-216. http://dx.doi.org/10.1007/s12028-009-9236-6

[60] Bosco, E., Marton, E., Feletti, A., Scarpa, B., Longatti, P., Zanatta, P., et al. (2011) Dynamic Monitors of Brain Function: A New Target in Neurointensive Care Unit. Critical Care, 15, R170. http://dx.doi.org/10.1186/cc10315

[61] Rossetti, A.O., Oddo, M., Logroscino, G. and Kaplan, P.W. (2010) Prognostication after Cardiac Arrest and Hypothermia: A Prospective Study. Annals of Neurology, 67, 301-307.

[62] Rossetti, A.O., Urbano, L.A., Delodder, F., Kaplan, P.W. and Oddo, M. (2010) Prognostic Value of Continuous EEG Monitoring during Therapeutic Hypothermia after Cardiac Arrest. Critical Care, 14, R173. http://dx.doi.org/10.1186/cc9276

[63] Rundgren, M., Westhall, E., Cronberg, T., Rosén, I. and Friberg, H. (2010) Continuous Amplitude-Integrated Electro encephalogram Predicts Outcome in Hypothermia-Treated Cardiac Arrest Patients. Critical Care Medicine, 38, 18381844. http://dx.doi.org/10.1097/CCM.0b013e3181eaa1e7

[64] Coates, S., Clarke, A., Davison, G. and Patterson, V. (2012) Tele-EEG in the UK: A Report of over 1,000 Patients. Journal of Telemedicine and Telecare, 18, 243-246. http://dx.doi.org/10.1258/jtt.2012.111003

[65] Palendeng, M.E., Zhang, Q., Pang, L. and Li, Y. (2012) EEG Data Compression to Monitor DoA in Telemedicine. Studies in Health Technology and Informatics, 178, 163-168.

[66] D’Arcy, R.C., Hajra, S.G., Liu, C., Sculthorpe, L.D. and Weaver, D.F. (2011) Towards Brain First-Aid: A Diagnostic Device for Conscious Awareness. IEEE Transactions on Biomedical Engineering, 58, 750-754. http://dx.doi.org/10.1109/TBME.2010.2090880

[67] Lasierra, N., Alesanco, A., Campos, C., Caudevilla, E., Fernández, J. and García, J. (2009) Experience of a Real-Time Tele-EEG Service. Annual International Conference of the IEEE Engineering in Medicine and Biology Society, 2009, 5211-5214.

[68] Campos, C., Caudevilla, E., Alesanco, A., Lasierra, N., Martinez, O., Fernández, J., et al. (2012) Setting up a Telemedicine Service for Remote Real-Time Video-EEG Consultation in La Rioja (Spain). International Journal of Medical Informatics, 81, 404-414. http://dx.doi.org/10.1016/j.ijmedinf.2012.01.006

[69] Toleikis, J.R. (2005) Intraoperative Monitoring Using Somatosensory Evoked Potentials. A Position Statement by the American Society of Neurophysiological Monitoring. Journal of Clinical Monitoring and Computing, 19, 241-258. http://dx.doi.org/10.1007/s10877-005-4397-0

[70] American Electroencephalographic Society (1994) Guidelines for Intraoperative Monitoring of Sensory Evoked Potentials. Journal of Clinical Neurophysiology, 11, 77-87. http://dx.doi.org/10.1097/00004691-199401000-00012

[71] American Electroencephalographic Society (1987) Guidelines for Intraoperative Monitoring of Sensory Evoked Potentials. Journal of Clinical Neurophysiology, 4, 397-416. http://dx.doi.org/10.1097/00004691-198710000-00005

[72] Guerit, J.M. (1999) EEG and Evoked Potentials in the Intensive Care Unit. Neurophysiologie Clinique, 29, $301-317$. http://dx.doi.org/10.1016/S0987-7053(99)90044-8

[73] Sloan, T.B. and Heyer, E.J. (2002) Anesthesia for Intraoperative Neurophysiologic Monitoring of the Spinal Cord. Journal of Clinical Neurophysiology, 19, 430-443. http://dx.doi.org/10.1097/00004691-200210000-00006

[74] Sloan, T. (2002) Anesthetics and the Brain. Anesthesiology Clinics of North America, 20, 265-292.

[75] International Organization of Societies for Electrophysiological Technology (OSET) (1999) Guidelines for Performing EEG and Evoked Potential Monitoring during Surgery. American Journal Of Electroneurodiagnostic Technology, 39, 257-277.

[76] Padberg, A.M., Russo, M.H., Lenke, L.G., Bridwell, K.H. and Komanetsky, R.M. (1996) Validity and Reliability of Spinal Cord Monitoring in Neuromuscular Spinal Deformity Surgery. Journal of Spinal Disorders, 9, 150-158. http://dx.doi.org/10.1097/00002517-199604000-00012

[77] Pelosi, L., Lamb, J., Grevitt, M., Mehdian, S.M.H., Webb, J.K. and Blumhardt, L.D. (2002) Combined Monitoring of Motor and Somatosensory Evoked Potentials in Orthopaedic Spinal Surgery. Clinical Neurophysiology, 113, 10821091. http://dx.doi.org/10.1016/S1388-2457(02)00027-5

[78] Guerit, J.M. (2010) Neurophysiological Testing in Neurocritical Care. Current Opinion in Critical Care, 16, 98-104. http://dx.doi.org/10.1097/MCC.0b013e328337541a

[79] Kim, S.M., Kim, S.H., Seo, D.W. and Lee, K.W. (2013) Intraoperative Neurophysiologic Monitoring: Basic Principles 
and Recent Update. Journal of Korean Medical Science, 28, 1261-1269.

http://dx.doi.org/10.3346/jkms.2013.28.9.1261

[80] Hillered, L., Vespa, P.M. and Hovda, D.A. (2005) Translational Neurochemical Research in Acute Human Brain Injury: the Current Status and Potential Future for Cerebral Microdialysis. Journal of Neurotrauma, 22, 3-41. http://dx.doi.org/10.1089/neu.2005.22.3

[81] Sarrafzadeh, A.S., Nagel, A., Czabanka, M., Denecke, T., Vajkoczy, P. and Plotkin, M. (2010) Imaging of HypoxicIschemic Penumbra with (18)F-Fluoromisonidazole PET/CT and Measurement of Related Cerebral Metabolism in Aneurysmal Subarachnoid Hemorrhage. Journal of Cerebral Blood Flow \& Metabolism, 30, 36-45. http://dx.doi.org/10.1038/jcbfm.2009.199

[82] Adamides, A.A., Rosenfeldt, F.L., Winter, C.D., Pratt, N.M., Tippett, N.J., Lewis, P.M., et al. (2009) Brain Tissue Lactate Elevations Predict Episodes of Intracranial Hypertension in Patients with Traumatic Brain Injury. Journal of the American College of Surgeons, 209, 531-539. http://dx.doi.org/10.1016/j.jamcollsurg.2009.05.028

[83] Oddo, M., Schmidt, J.M., Carrera, E., Badjatia, N., Connolly, E.S., Presciutti, M., et al. (2008) Impact of Tight Glycemic Control on Cerebral Glucose Metabolism after Severe Brain Injury: A Microdialysis Study. Critical Care Medicine, 36, 3233-3238.

[84] Meierhans, R., Béchir, M., Ludwig, S., Sommerfeld, J., Brandi, G., Haberthür, C., et al. (2010) Brain Metabolism Is Significantly Impaired at Blood Glucose below $6 \mathrm{mM}$ and Brain Glucose Below $1 \mathrm{mM}$ in Patients with Severe Traumatic Brain Injury. Critical Care, 14, R13. http://dx.doi.org/10.1186/cc8869

[85] Ko, S.B., Choi, H.A., Parikh, G., Helbok, R., Schmidt, J.M., Lee, K., et al. (2011) Multimodality Monitoring for Cerebral Perfusion Pressure Optimization in Comatose Patients with Intracerebral Hemorrhage. Stroke, 42, 3087-3092. http://dx.doi.org/10.1161/STROKEAHA.111.623165

[86] Schmidt, J.M., Ko, S.B., Helbok, R., Kurtz, P., Stuart, R.M., Presciutti, M., et al. (2011) Cerebral Perfusion Pressure Thresholds for Brain Tissue Hypoxia and Metabolic Crisis after Poor-Grade Subarachnoid Hemorrhage. Stroke, 42, 1351-1356. http://dx.doi.org/10.1161/STROKEAHA.110.596874

[87] Oddo, M., Milby, A., Chen, I., Frangos, S., MacMurtrie, E., Maloney-Wilensky, E., et al. (2009) Hemoglobin Concentration and Cerebral Metabolism in Patients with Aneurysmal Subarachnoid Hemorrhage. Stroke, 40, 1275-1281. http://dx.doi.org/10.1161/STROKEAHA.110.596874

[88] Diringer, M.N., Bleck, T.P., Claude Hemphill 3rd, J., Menon, D., Shutter, L., Vespa, P., et al. (2011) Critical Care Management of Patients Following Aneurysmal Subarachnoid Hemorrhage: Recommendations from the Neurocritical Care Society’s Multidisciplinary Consensus Conference. Neurocritical Care, 15, 211-240. http://dx.doi.org/10.1007/s12028-011-9605-9

[89] Bellander, B.M., Cantais, E., Enblad, P., Hutchinson, P., Nordström, C.H., Robertson, C., et al. (2004) Consensus Meeting on Microdialysis in Neurointensive Care. Intensive Care Medicine, 30, 2166-2169. http://dx.doi.org/10.1007/s00134-004-2461-8

[90] Andrews, P.J., Citerio, G., Longhi, L., Polderman, K., Sahuquillo, J. and Vajkoczy, P. (2008) NICEM Consensus on Neurological Monitoring in Acute Neurological Disease. Intensive Care Medicine, 34, 1362-1370. http://dx.doi.org/10.1007/s00134-008-1103-y

[91] Timofeev, I., Carpenter, K.L., Nortje, J., Al-Rawi, P.G., O’Connell, M.T., Czosnyka, M., et al. (2011) Cerebral Extracellular Chemistry and Outcome Following Traumatic Brain Injury: A Microdialysis Study of 223 Patients. Brain, 134, 484-494. http://dx.doi.org/10.1093/brain/awq353

[92] Poca, M.A., Sahuquillo, J., Vilalta, A., Rios, J.D.L., Robles, A. and Exposito, L. (2006) Percutaneous Implantation of Cerebral Microdialysis Catheters by Twist-Drill Craniostomy in Neurocritical Patients: Description of the Technique and Results of a Feasibility Study in 97 Patients. Journal of Neurotrauma, 23, 1510-1517. http://dx.doi.org/10.1089/neu.2006.23.1510

[93] Verweij, B.H., Amelink, G.J. and Muizelaar, J.P. (2007) Current Concepts of Cerebral Oxygen Transport and Energy Metabolism after Severe Traumatic Brain Injury. Progress in Brain Research, 161, 111-124. http://dx.doi.org/10.1016/S0079-6123(06)61008-X

[94] Feldman, Z. and Robertson, C.S. (1997) Monitoring of Cerebral Hemodynamics with Jugular Bulb Catheters. Critical Care Clinics, 13, 51-77. http://dx.doi.org/10.1016/S0749-0704(05)70296-7

[95] Macmillan, C.S. and Andrews, P.J. (2000) Cerebrovenous Oxygen Saturation Monitoring Considerations and Clinical Relevance. Intensive Care Medicine, 26, 1028-1036. http://dx.doi.org/10.1007/s001340051315

[96] Reilly, P.L. (2001) Brain Injury: The Pathophysiology of the First Hours. "Talk and Die Revisited”. Journal of Clinical Neuroscience, 8, 398-403. http://dx.doi.org/10.1054/jocn.2001.0916

[97] Rosenthal, G., Hemphill 3rd, J.C., Sorani, M., Martin, C., Morabito, D., Obrist, W.D., et al. (2008) Brain Tissue Oxygen Tension Is More Indicative of Oxygen Diffusion than Oxygen Delivery and Metabolism in Patients with Traumatic 
Brain Injury. Critical Care Medicine, 36, 1917-1924. http://dx.doi.org/10.1097/CCM.0b013e3181743d77

[98] Jaeger, M., Dengl, M., Meixensberger, J. and Schuhmann, M.U. (2010) Effects of Cerebrovascular Pressure Reactivity-Guided Optimization of Cerebral Perfusion Pressure on Brain Tissue Oxygenation after Traumatic Brain Injury. Critical Care Medicine, 38, 1343-1347.

[99] Jaeger, M., Schuhmann, M.U., Soehle, M., Nagel, C. and Meixensberger, J. (2007) Continuous Monitoring of Cerebrovascular Autoregulation after Subarachnoid Hemorrhage by Brain Tissue Oxygen Pressure Reactivity and Its Relation to Delayed Cerebral Infarction. Stroke, 38, 981-986. http://dx.doi.org/10.1161/01.STR.0000257964.65743.99

[100] Rangel-Castilla, L., Lara, L.R., Gopinath, S., Swank, P.R., Valadka, A. and Robertson, C. (2010) Cerebral Hemodynamic Effects of Acute Hyperoxia and Hyperventilation after Severe Traumatic Brain Injury. Journal of Neurotrauma, 27, 1853-1863. http://dx.doi.org/10.1089/neu.2010.1339

[101] Oddo, M., Nduom, E., Frangos, S., MacKenzie, L., Chen, I., Maloney-Wilensky, E., et al. (2010) Acute Lung Injury Is an Independent Risk Factor for Brain Hypoxia after Severe Traumatic Brain Injury. Neurosurgery, 67, 338-344. http://dx.doi.org/10.1227/01.NEU.0000371979.48809.D9

[102] Le Roux, P.D. (2011) Anemia and Transfusion after Subarachnoid Hemorrhage. Neurocritical Care, 15, 342-353. http://dx.doi.org/10.1007/s12028-011-9582-z

[103] Maloney-Wilensky, E., Gracias, V., Itkin, A., Hoffman, K., Bloom, S., Yang, W., et al. (2009) Brain Tissue Oxygen and Outcome after Severe Traumatic Brain Injury: A Systematic Review. Critical Care Medicine, 37, 2057-2063.

[104] Oddo, M., Levine, J.M., Mackenzie, L., Frangos, S., Feihl, F., Kasner, S.E., et al. (2011) Brain Hypoxia Is Associated with Short-Term Outcome after Severe Traumatic Brain Injury Independent of Intracranial Hypertension and Low Cerebral Perfusion Pressure. Neurosurgery, 69, 1037-1045.

[105] Bratton, S.L., Chestnut, R.M., Ghajar, J., Hammond, F.M., Harris, O.A., Hartl, R., et al. (2007) Guidelines for the Management of Severe Traumatic Brain Injury. X. Brain Oxygen Monitoring and Thresholds. Journal of Neurotrauma, 24, S65-S70. http://dx.doi.org/10.1089/neu.2007.9986

[106] Hänggi, D. (2011) Monitoring and Detection of Vasospasm II: EEG and Invasive Monitoring. Neurocritical Care, 15 318-323. http://dx.doi.org/10.1007/s12028-011-9583-y

[107] Bohman, L.E., Heuer, G.G., Macyszyn, L., Maloney-Wilensky, E., Frangos, S., Le Roux, P.D., et al. (2011) Medical Management of Compromised Brain Oxygen in Patients with Severe Traumatic Brain Injury. Neurocritical Care, 14, 361-369. http://dx.doi.org/10.1007/s12028-011-9526-7

[108] Nangunoori, R., Maloney-Wilensky, E., Stiefel, M., Park, S., Kofke, W.A., Levine, J.M., et al. (2012) Brain Tissue Oxygenbased Therapy and Outcome after Severe Traumatic Brain Injury: A Systematic Literature Review. Neurocritical Care, 17, 131-138. http://dx.doi.org/10.1007/s12028-011-9621-9

[109] Hoshi, Y. (2007) Functional Near-Infrared Spectroscopy: Current Status and Future Prospects. Journal of Biomedical Optics, 12, Article ID 062106. http://dx.doi.org/10.1117/1.2804911

[110] Rolfe, P. (2000) In Vivo Near-Infrared Spectroscopy. Annual Review of Biomedical Engineering, 2, 715-754. http://dx.doi.org/10.1146/annurev.bioeng.2.1.715

[111] Wolf, M., Ferrari, M. and Quaresima, V. (2007) Progress of Near-Infrared Spectroscopy and Topography for Brain and Muscle Clinical Applications. Journal of Biomedical Optics, 12, Article ID: 062104. http://dx.doi.org/10.1117/1.2804899

[112] Ghosh, A., Elwell, C. and Smith, M. (2012) Cerebral Near-Infrared Spectroscopy in Adults: A Work in Progress. Anesthesia \& Analgesia, 115, 1373-1383. http://dx.doi.org/10.1213/ANE.0b013e31826dd6a6

[113] Gazzaniga, M.S. (2000) Regional Differences in Cortical Organization. Science, 289, 1887-1888. http://dx.doi.org/10.1126/science.289.5486.1887

[114] Gazzaniga, M.S. (2005) What's on Your Mind? New Science, 186, 48-50.

[115] Ferrari, M., Wilson, D.A., Hanley, D.F., Hartmann, J.F. and Traystman, R.J. (1989) Determination of Cerebral Venous Hemoglobin Saturation by Derivative near Infrared Spectroscopy. Advances in Experimental Medicine and Biology, 248, 47-53. http://dx.doi.org/10.1007/978-1-4684-5643-1_6

[116] Ferrari, M. and Quaresima, V. (2012) A Brief Review on the History of Human Functional Near-Infrared Spectroscopy (fNIRS) Development and Fields of Application. Neuroimage, 63, 921-935. http://dx.doi.org/10.1016/j.neuroimage.2012.03.049

[117] Calderon-Arnulphi, M., Alaraj, A. and Slavin, K.V. (2009) Near Infrared Technology in Neuroscience: Past, Present and Future. Neurological Research, 31, 605-614. http://dx.doi.org/10.1179/174313209X383286

[118] Wallois, F., Mahmoudzadeh, M., Patil, A. and Grebe, R. (2012) Usefulness of Simultaneous EEG-NIRS Recording in Language Studies. Brain and Language, 121, 110-123. http://dx.doi.org/10.1016/j.bandl.2011.03.010

[119] Ito, H., Ibaraki, M., Kanno, I., Fukuda, H. and Miura, S. (2005) Changes in the Arterial Fraction of Human Cerebral 
Blood Volume during Hypercapnia and Hypocapnia Measured by Positron Emission Tomography. Journal of Cerebral Blood Flow \& Metabolism, 25, 852-857. http://dx.doi.org/10.1038/sj.jcbfm.9600076

[120] Thavasothy, M., Broadhead, M., Elwell, C., Peters, M. and Smith, M. (2002) A Comparison of Cerebral Oxygenation as Measured by the NIRO 300 and the INVOS 5100 Near-Infrared SPECTROPHOTOMETERS. Anaesthesia, 57, 9991006. http://dx.doi.org/10.1046/j.1365-2044.2002.02826.x

[121] Giustiniano, E., Alfano, A., Battistini, G.M., Gavazzeni, V., Spoto, M.R. and Cancellieri, F. (2010) Cerebral Oximetry during Carotid Clamping: Is Blood Pressure Raising Necessary? Journal of Cardiovascular Medicine, 11, 522-528. http://dx.doi.org/10.2459/JCM.0b013e32833246e7

[122] Picton, P., Chambers, J., Shanks, A. and Dorje, P. (2010) The Influence of Inspired Oxygen Fraction and End-Tidal Carbon Dioxide on Post-Crossclamp Cerebral Oxygenation during Carotid Endarterectomy under General Anesthesia. Anesthesia \& Analgesia, 110, 581-587. http://dx.doi.org/10.1213/ANE.0b013e3181c5f160

[123] Stoneham, M.D., Lodi, O., de Beer, T.C. and Sear, J.W. (2008) Increased Oxygen Administration Improves Cerebral Oxygenation in Patients Undergoing Awake Carotid Surgery. Anesthesia \& Analgesia, 107, 1670-1675. http://dx.doi.org/10.1213/ane.0b013e318184d6c3

[124] Mauermann, W.J., Crepeau, A.Z., Pulido, J.N., Lynch, J.J., Lobbestael, A., Oderich, G.S., et al. (2013) Comparison of Electroencephalography and Cerebral Oximetry to Determine the Need for In-Line Arterial Shunting in Patients Undergoing Carotid Endarteriectomy. Journal of Cardiothoracic and Vascular Anesthesia, 27, 1253-1259. http://dx.doi.org/10.1053/j.jvca.2013.02.013

[125] Pedrini, L., Magnoni, F., Sensi, L., Pisano, E., Ballestrazzi, M.S., Cirelli, M.R., et al. (2012) Is Near-Infrared Spectroscopy a Reliable Method to Eveluate Clamping Ischemia during Carotid Surgery? Stroke Research and Treatment, 2012, Article ID 156975.

[126] Uchino, H., Nakamura, T., Kuroda, S., Houkin, K., Murata, J. and Saito, H. (2012) Intraoperative Dual Monitoring during Carotid Endarterectomy Using Motor Evoked Potentials and Near-Infrared Spectroscopy. World Neurosurgery, 78, 651-657. http://dx.doi.org/10.1016/j.wneu.2011.10.039

[127] Vohra, H.A., Modi, A. and Ohri, S.K. (2009) Does Use of Intra-Operative Cerebral Regional Oxygen Saturation Monitoring during Cardiac Surgery Lead to Improved Clinical Outcomes? Interactive CardioVasc Thoracic Surgery, 9, 318-322. http://dx.doi.org/10.1510/icvts.2009.206367

[128] Murkin, J.M. and Arango, M. (2009) Near-Infrared Spectroscopy as an Index of Brain and Tissue Oxygenation. British Journal of Anaesthesia, 103, i3-i13. http://dx.doi.org/10.1093/bja/aep299

[129] Selnes, O.A., Gottesman, R.F., Grega, M.A., Baumgartner, W.A., Zeger, S.L. and McKhann, G.M. (2012) Cognitive and Neurologic Outcomes after Coronary-Artery Bypass Surgery. The New England Journal of Medicine, 366, 250257. http://dx.doi.org/10.1056/NEJMra1100109

[130] Smith, M. (2011) Shedding Light on the Adult Brain: A Review of the Clinical Applications of Near-Infrared Spectroscopy. Philosophical Transactions of the Royal Society A, 369, 4452-4469. http://dx.doi.org/10.1098/rsta.2011.0242

[131] D’Alessio, J.G., Rosenblum, M., Shea, K.P. and Freitas, D.G. (1995) A Retrospective Comparison of Interscalene Block and General Anesthesia for Ambulatory Surgery Shoulder Arthroscopy. Regional Anesthesia, 20, 62-68.

[132] Friedman, D.J., Parnes, N.Z., Zimmer, Z., Higgins, L.D. and Warner, J.J. (2009) Prevalence of Cerebrovascular Events during Shoulder Surgery and Association with Patient Position. Orthopedics, 32, 256.

[133] Dippmann, C., Winge, S. and Nielsen, H.B. (2010) Severe Cerebral Desaturation during Shoulder Arthroscopy in the Beach-Chair Position. Arthroscopy, 26, S148-S150. http://dx.doi.org/10.1016/j.arthro.2010.03.012

[134] Fischer, G.W., Torrillo, T.M., Weiner, M.M. and Rosenblatt, M.A. (2009) The Use of Cerebral Oximetry as a Monitor of the Adequacy of Cerebral Perfusion in a Patient Undergoing Shoulder Surgery in the Beach Chair Position. Pain Practice, 9, 304-307. http://dx.doi.org/10.1111/j.1533-2500.2009.00282.x

[135] Murphy, G.S., Szokol, J.W., Marymont, J.H., Greenberg, S.B., Avram, M.J., Vender, J., et al. (2010) Cerebral Oxygen Desaturation Events Assessed by Near-Infrared Spectroscopy during Shoulder Arthroscopy in the Beach Chair and Lateral Decubitus Positions. Anesthesia \& Analgesia, 111, 496-505. http://dx.doi.org/10.1213/ANE.0b013e3181e33bd9

[136] Li, Z., Wang, Y., Li, Y., Wang, Y., Li, J. and Zhang, L. (2010) Wavelet Analysis of Cerebral Oxygenation Signal Measured by Near Infrared Spectroscopy in Subjects with Cerebral Infarction. Microvascular Research, 80, 142-147. http://dx.doi.org/10.1016/j.mvr.2010.02.004

[137] Leal-Noval, S.R., Cayuela, A., Arellano-Orden, V., Marín-Caballos, A., Padilla, V., Ferrándiz-Millón, C., et al. (2010) Invasive and Noninvasive Assessment of Cerebral Oxygenation in Patients with Severe Traumatic Brain Injury. Intensive Care Medicine, 36, 1309-1317. http://dx.doi.org/10.1007/s00134-010-1920-7

[138] Debevec, T. and Mekjavic, I.B. (2012) Short Intermittent Hypoxic Exposures Augment Ventilation but Do Not Alter Regional Cerebral and Muscle Oxygenation during Hypoxic Exercise. Respiratory Physiology \& Neurobiology, 181, 
132-142. http://dx.doi.org/10.1016/j.resp.2012.02.008

[139] Ferrari, M., Muthalib, M. and Quaresima, V. (2011) The Use of Near-Infrared Spectroscopy in Understanding Skeletal Muscle Physiology: Recent Developments. Philosophical Transactions of the Royal Society A, 28, 4577-4590. http://dx.doi.org/10.1098/rsta.2011.0230

[140] Tax, N., Urlesberger, B., Binder, C., Pocivalnik, M., Morris, N. and Pichle, G. (2013) The Influence of Perinatal Asphyxia on Peripheral Oxygenation and Perfusion in Neonates. Early Human Development, 89, 483-486. http://dx.doi.org/10.1016/j.earlhumdev.2013.03.011

[141] Mittnacht, A.J. (2010) Near Infrared Spectroscopy in Children at High Risk of Low Perfusion. Current Opinion in Anaesthesiology, 23, 342-347. http://dx.doi.org/10.1097/ACO.0b013e3283393936

[142] Vajkoczy, P., Roth, H., Horn, P., Lucke, T., Thomé, C., Hubner, U., et al. (2000) Continuous Monitoring of Regional Cerebral Blood Flow: Experimental and Clinical Validation of a Novel Thermal Diffusion Microprobe. Journal of Neurosurgery, 93, 265-274. http://dx.doi.org/10.3171/jns.2000.93.2.0265

[143] Muench, E., Horn, P., Bauhuf, C., Roth, H., Philipps, M., Hermann, P., et al. (2007) Effects of Hypervolemia and Hypertension on Regional Cerebral Blood Flow, Intracranial Pressure, and Brain Tissue Oxygenation after Subarachnoid Hemorrhage. Critical Care Medicine, 35, 1844-1851.

[144] Rosenthal, G., Sanchez-Mejia, R.O., Phan, N., Hemphill 3rd, J.C., Martin, C. and Manley, G.T. (2011) Incorporating a Parenchymal Thermal Diffusion Cerebral Blood Flow Probe in Bedside Assessment of Cerebral Autoregulation and Vasoreactivity in Patients with Severe Traumatic Brain Injury. Journal of Neurosurgery, 114, 62-70. http://dx.doi.org/10.3171/2010.6.JNS091360

[145] Ponce, L.L., Pillai, S., Cruz, J., Li, X., Julia, H., Gopinath, S., et al. (2012) Position of the Probe Determines Prognostic Information of Brain Tissue PO2 in Severe Traumatic Brain Injury. Neurosurgery, 70, 1492-1502. http://dx.doi.org/10.1227/NEU.0b013e31824ce933

[146] Helbok, R., Madineni, R.C., Schimedt, M.J., Kurtz, P., Fernandez, L., Ko, S.B., et al. (2011) Intracerebral Monitoring of Silent Infarcts after Subarachnoid Hemorrhage. Neurocritical Care, 14, 162-167. http://dx.doi.org/10.1007/s12028-010-9472-9

[147] Maloney-Wilensky, E. and Le Roux, P. (2010) The Physiology Behind Direct Brain Oxygen Monitors and Practical Aspects of Their Use. Child's Nervous System, 26, 419-430. http://dx.doi.org/10.1007/s00381-009-1037-x

[148] Green, J.A., Pellegrini, D.C., Vanderkolk, W.E., Figueroa, B.E. and Eriksson, E.A. (2013) Goal Directed Brain Tissue Oxygen Monitoring versus Conventional Management in Truamtic Brain Injury: An Analysis of in Hospital Recovery. Neurocritical Care, 18, 20-25. http://dx.doi.org/10.1007/s12028-012-9797-7

[149] Bouzat, P., Sala, N., Payen, J.F. and Oddo, M. (2013) Beyond Intracranial Pressure: Optimization of Cerebral Blood Flow, Oxygen, and Substrate Delivery after Traumatic Brain Injury. Annals of Intensive Care, 10, 3-23.

[150] Salerud, E.G. and Nilsson, G.E. (1986) Integrating Probe for Tissue Laser Doppler Flowmeters. Medical and Biological Engineering and Computing, 24, 415-419. http://dx.doi.org/10.1007/BF02442697

[151] Salerud, E.G. and Öberg, P.Å. (1987) Single-Fiber Laser Doppler Flowmetry. Medical and Biological Engineering and Computing, 25, 329-334. http://dx.doi.org/10.1007/BF02447433

[152] Arbit, E., DiResta, G.R., Bedford, R.F., Shah, N.K. and Galicich, J.H. (1989) Intraoperative Measurement of Cerebral and Tumor Blood Flow with Laser-Doppler Flowmetry. Neurosurgery, 24, 166-170. http://dx.doi.org/10.1227/00006123-198902000-00003

[153] Iadecola, C. and Reis, D.J. (1990) Continuous Monitoring of Cerebrocortical Blood Flow during Stimulation of the Cerebellar Fastigial Nucleus. Journal of Cerebral Blood Flow \& Metabolism, 10, 608-617. http://dx.doi.org/10.1038/jcbfm.1990.112

[154] Haberl, R.L., Heizer, M.L., Marmarou, A. and Ellis, E.F. (1989) Laser-Doppler Assessment of Brain Microcirculation: Effect of Systemic Alterations. American Journal of Physiology, Heart and Circulatory, 256, H1247-H1254.

[155] Haberl, R.L., Heizer, M.L. and Ellis, E.F. (1989) Laser-Doppler Assessment of Brain Microcirculation: Effect of Local Alterations. American Journal of Physiology, Heart and Circulatory, 256, H1255-H1260.

[156] Lindsberg, P.J., O’Neill, J.T., Paakkari, I.A., Hallenbeck, J.M. and Feuerstein, G. (1989) Validation of Laser-Doppler Flowmetry in Measurement of Spinal Cord Blood Flow. American Journal of Physiology, Heart and Circulatory, 257, H674-H680.

[157] Zweifel, C., Czonyka, M., Lavinio, A., Castellani, G., Kim, D.J., Carrera, E., et al. (2010) A Comparison Study of Cerebral Autoregulation Assessed with Transcranial Doppler and Cortical Laser Doppler Flowmetry. Neurological Research, 32, 425-428. http://dx.doi.org/10.1179/174313209X459165

[158] Topcuoglu, M.A. (2012) Transcranial Doppler Ultrasound in Neurovascular Diseases: Diagnostic and Therapeutic Aspects. Journal of Neurochemistry, 123, 39-51. http://dx.doi.org/10.1111/j.1471-4159.2012.07942.X 
[159] Edmonds Jr., H.L., Isley, M.R., Sloan, T.B., Alexandrov, A.V. and Razumovsky, A.Y. (2011) American Society of Neurophysiologic Monitoring and American Society of Neuroimaging Joint Guidelines for Transcranial Doppler Ultrasonic Monitoring. Journal of Neuroimaging, 21, 177-183. http://dx.doi.org/10.1111/j.1552-6569.2010.00471.x

[160] Kassah, M.Y., Majid, A., Farooq, M.U., Azhary, H., Hershey, L.A., Bednarczyk, E.M., et al. (2007) Transcranial Doppler: An Introduction for Primary Care Physicians. Journal of the American Board of Family Medicine, 20, 65-71. http://dx.doi.org/10.3122/jabfm.2007.01.060128

[161] Greke, C., Neulen, A., Kantelhardt, S.R., Birkenmayer, A., Vollmer, F.C., Thiemann, I., et al. (2013) Image-Guided Transcranial Doppler Sonography for Monitoring of Defined Segments of Intracranial Arteries. Journal of Neurosurgical Anesthesiology, 25, 55-61. http://dx.Doi.org/10.1097/ANA.0b013e31826b3d55

[162] Stendel, R., Pietilä, T., Al Hassan, A.A., Schillingb, A. and Brock, M. (2000) Intraoperative Microvascular Doppler Ultrasonography in Cerebral Aneurysm Surgery. Journal of Neurology, Neurosurgery, and Psychiatry, 68, 29-35. http://dx.doi.org/10.1136/jnnp.68.1.29 
Scientific Research Publishing (SCIRP) is one of the largest Open Access journal publishers. It is currently publishing more than 200 open access, online, peer-reviewed journals covering a wide range of academic disciplines. SCIRP serves the worldwide academic communities and contributes to the progress and application of science with its publication.

Other selected journals from SCIRP are listed as below. Submit your manuscript to us via either submit@scirp.org or Online Submission Portal.
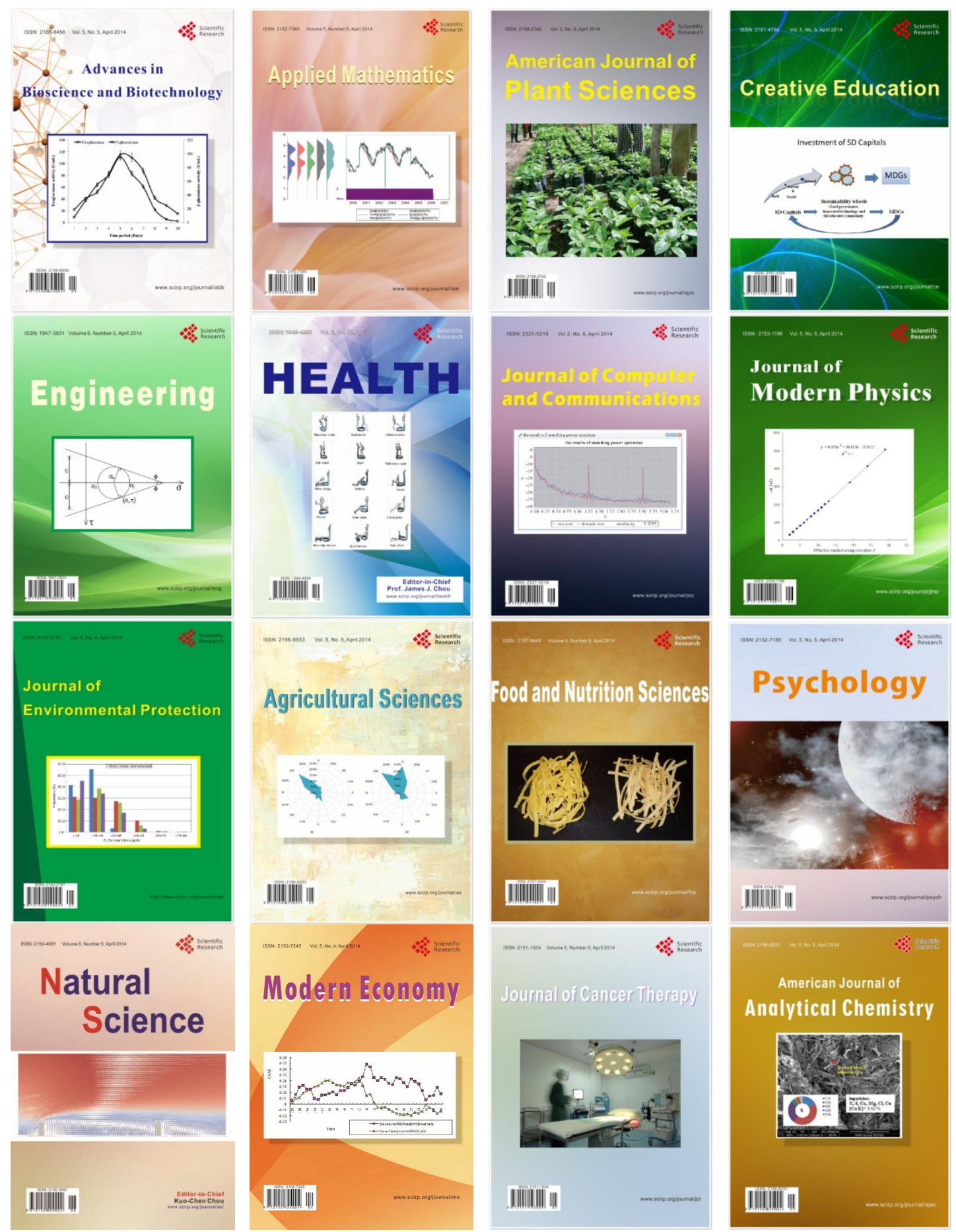